NBER WORKING PAPER SERIES

\title{
THE ELUSIVE GAINS FROM INTERNATIONAL FINANCIAL INTEGRATION
}

\author{
Pierre-Olivier Gourinchas \\ Olivier Jeanne
}

Working Paper 9684

http://www.nber.org/papers/w9684

\section{NATIONAL BUREAU OF ECONOMIC RESEARCH 1050 Massachusetts Avenue Cambridge, MA 02138}

May 2003

We wish to thank for their comments, without implicating, Charles Engel, Itay Goldstein, Enrique Mendoza as well as seminar participants at UC Berkeley, Cornell, the Federal Reserve Board, Harvard/MIT, the IMF, NYU, Princeton, UCLA, Virginia, Yale, the 2002 SED meeting (NY), theWorld Bank-Georgetown- CFS conference on Pnancial globalization, the 2002 NBER summer Institute, the 2002 LACEA-IADB-UTDT conference (Buenos Aires) and the IV RTN conference on capital markets (Dublin). The views expressed herein are those of the authors and not necessarily those of the National Bureau of Economic Research.

(C2003 by Pierre-Olivier Gourinchas and Olivier Jeanne. All rights reserved. Short sections of text not to exceed two paragraphs, may be quoted without explicit permission provided that full credit including Cnotice, is given to the source. 
The Elusive Gains from International Financial Integration

Pierre-Olivier Gourinchas and Olivier Jeanne

NBER Working Paper No. 9684

May 2003

JEL No. F2, F3, F43, E13, O11

\section{$\underline{\text { ABSTRACT }}$}

Standard theoretical arguments tell us that countries with relatively little capital benefit from financial integration as foreign capital flows in and speeds up the process of convergence. We show in a calibrated neoclassical model that conventionally measured welfare gains from this type of convergence appear relatively limited for the typical emerging country. The welfare gain from switching from financial autarky to perfect capital mobility is roughly equivalent to a one percent permanent increase in domestic consumption for the typical emerging economy. This is negligible relative to the potential welfare gain of a take-off in domestic productivity of the magnitude observed in some of these countries.

Pierre Olivier Gourinchas

Department of Economics

Princeton University

311 Fisher Hall

Princeton, NJ 08540

and NBER

pog@princeton.edu
Olivier Jeanne

International Monetary Fund

ojeanne@imf.org 


\section{Introduction}

Ask an economist, and the benefit of international financial integration that first comes to his or her mind is likely to involve, in one way or another, the efficiency of laissez-faire. A more open and competitive international capital market induces a more efficient international allocation of capital. A development-minded economist, in particular, will point to the impact of capital flows from developed (capital-abundant) to less developed (capital-scarce) countries on economic growth and convergence. Indeed, one of the main motivation behind the push towards the international financial integration of less developed countries has been to accelerate their growth by attracting foreign capital. ${ }^{1}$

We understand these benefits well enough in theory, but how large are they in practice? This paper presents a new piece of evidence, based of the calibration of a simple neoclassical growth model. We choose the neoclassical framework for two reasons. First, it is one where international financial integration is desirable for well-known reasons. Second, this model has increasingly been adopted as the benchmark framework in the literature on growth and convergence in an international perspective. As a result, we can rely on this literature to calibrate the model, and compare the welfare effects of different policies, including capital account opening.

We present two versions of the neo-classical model. The first -and simplest- one is a variant of the Ramsey-Cass-Koopman model where countries accumulate physical capital only. It serves to motivate and provide some intuition for our results. The second one proposes a higher level of detail and realism by introducing human capital accumulation in a 'Macro-Mincer' framework. Our main finding is that while financial openness increases domestic welfare, and while this benefit can be significant for some countries, it is not very large on average. For the typical non-OECD country, the welfare gain from switching from financial autarky to perfect capital mobility is equivalent to a permanent increase in consumption of about one percent. This benefit is of the same order of magnitude as the cost of economic fluctuations (in less developed countries), and of an order of magnitude smaller than the gains that development economists and policymakers seek to achieve. For example, we find that eliminating 25 percent of the productivity gap with the United Statesa productivity increase smaller than the magnitude experienced in post-war Singapore, HongKong or Israel - yields a welfare benefit that is more than one hundred times larger!

Interestingly, we find that the gains from international financial integration may be relatively small even for countries that receive a lot of capital inflows. In the simple Ramsey model, for example, the typical non-OECD country has a gain of only 1 percent in spite of the fact that inflows more than double its stock of capital. This apparent disconnect comes

\footnotetext{
${ }^{1}$ See Eichengreen and Mussa (1998) (p.12): "The classic case for international capital mobility is wellknown but worth restating. Flows from capital-abundant to capital-scarce countries raise welfare in the sending and receiving countries alike on the assumption that the marginal product of capital is higher in the latter than in the former. Free capital movements thus permit a more efficient global allocation of savings and direct resources toward their most productive uses.", or Fischer (1998) (p. 2): "Put abstractly, free capital movements facilitate an efficient global allocation of savings and help channel ressources to their most productive uses, thus increasing economic growth and welfare".
} 
from the essentially transitory nature of the distortion induced by imperfect capital mobility. A capital-scarce country that restricts the entry of foreign capital bears a distortion that is proportional to the wedge between the domestic and foreign returns on investment. Even if the capital account restriction remains in place forever, the distortion endogenously vanishes over time as the country accumulates capital domestically. The average distortion, as a result, is much lower than the initial distortion - and the initial capital inflows-might suggest.

We also find that international financial integration does not lead to a significant degree of convergence between developed and less developed countries. The reason for that result is straightforward. In the neoclassical model, the gap in GDP per capita between developed and less developed countries can be decomposed into a transitory component due to capital scarcity and a permanent component due to differences in productivity and domestic distortions. For international financial integration to have a substantial impact on convergence, the first component would have to be relatively important. The data, however, suggest that the opposite is true: less developed countries have a lower income per capita mainly because they are less productive or their economy suffers from domestic distortions, not because they are capital-scarce.

We believe that our findings have important implications for the research agenda on financial globalization. The recent crises have certainly dampened the hope that capital account liberalization provides a smooth road to growth and development, and the time seems ripe for re-examining the benefits and costs of international financial integration. This paper suggests that if the benefits of international financial integration are large, they must occur through channels that are not in the standard neoclassical framework. Moreover, these channels can explain large gains (in our metric) only if international financial integration raises the productivity of less developed countries. ${ }^{2} \mathrm{~A}$ challenge for future research is to identify the possible channels and test their empirical relevance. ${ }^{3}$

Our findings also have implications for the recent debate on reforming the "international financial architecture". A commonly held view is that capital flows to less developed economies are excessively low, and that the international financial architecture should be designed so as to increase the access of less developed countries to the international financial market. This paper suggests that even if capital flows were below the efficient level, the potential gains from mitigating this inefficiency might be quite moderate. Countries have much more to gain from upgrading their domestic engines of growth and development than from attracting foreign capital. ${ }^{4}$

This paper contributes to a growing literature on the benefits of capital account liberalization for less developed countries. A number of papers have attempted to answer the same

\footnotetext{
${ }^{2}$ The literature on trade liberalization has reached a similar conclusion. In calibrated neoclassical models the gains from trade liberalization typically amount to less than 1 percent of GDP (de Melo and Tarr (1992)). This has led some authors in the trade literature to conclude that if free trade yields large welfare gains, it must be because of its impact on productivity (Rutherford and Tarr (2002)).

${ }^{3}$ Possible channels are discussed in the concluding comments.

${ }^{4}$ Of course, a country that increases its productivity also makes itself more attractive to foreign investors. Our claim is that the country benefits much more from the productivity increase itself than from the resulting capital inflows.
} 
question as we do, but on the basis of cross-country regressions. ${ }^{5}$ The results are pretty heterogenous, ranging from no impact of capital account opening on growth (Rodrik (1998)) to a more or less significant positive impact (see Edison, Levine, Ricci and Sloek (2002), for a review). At the optimistic end of the spectrum Bekaert, Harvey and Lundblad (2002) and Henry (2003) find that opening the stock market to foreign investors boosts growth by 1 to 2 percent for five years in a row. Such a result, however, is not obvious to translate in terms of domestic welfare. How permanent is the impact of capital account opening on growth? Is the level of output affected in the long-run? What share of the output increase is transferred to foreign investors? These questions are crucial in assessing the welfare impact of capital account opening, and can be addressed only by looking at the data through the lenses of an explicit model.

Another branch of literature looks at the benefit of international financial integration in terms of portfolio diversification. A number of papers present quantitative estimates based on calibrated models, comparable to ours since they are expressed in the same metric. The reported results vary enormously, with most papers finding gains from international risk-sharing smaller than 0.5 percent (e.g., Backus, Kehoe and Kydland (1992)) and some studies reporting larger welfare gains (see e.g. Obstfeld (1994)). ${ }^{6}$

Whatever the reasons behind these differences, there is widespread consensus on the fact that the world is remote from the extent of risk-sharing that takes place in these models-a gap between the theory and reality that is multifaceted and has been abundantly documented in the literature on the "puzzles" of international finance (Obstfeld and Rogoff (2000)). If anything, this gap seems even wider for the emerging market countries than for developed ones - the "sudden stops" in capital flows documented by Calvo and Reinhart (2000) seem especially difficult to interpret in terms of optimal risksharing. ${ }^{7}$ For all these reasons, we view capital accumulation and growth as potentially better candidates than international risk-sharing to understand the benefits of international financial integration for developing economies.

Our results are consistent with the recent developments of the literature on growth and convergence in international perspective. In contrast with early papers that stressed factor accumulation as a source of growth (Mankiw, Romer and Weil (1992); Barro, Mankiw and Sala-i-Martin (1995)), the literature has moved towards the view that total factor productivity rather than factor accumulation accounts for most of income differences across countries (Hall and Jones (1999); Easterly and Levine (2001)).

This literature has not looked at the impact of international financial integration on growth and convergence. We present a 'development accounting exercise' that highlights the

\footnotetext{
${ }^{5}$ Some papers present estimates of the benefits of international financial integration based on calibrated models, as we do here, but focus on developed economies. For example, Mendoza and Tesar (1998) estimate the impact of integration in models where the taxation of capital is endogenous. Table 2 in Mendoza and Tesar (1998) suggest that the welfare benefit of integration is small-less than 0.5 percent of permanent consumption in the United States.

${ }^{6}$ See Athanasoulis and van Wincoop (2000) for a discussion of the literature and an attempt to account for these differences.

${ }^{7}$ Somewhat paradoxically, the theoretical welfare gains from international risksharing are estimated to be larger when the model is calibrated with reference to less developed economies because they are more volatile (see Pallage and Robe (2003)).
} 
relative contributions of factor accumulation, productivity and a conditional convergence gap that financial integration eliminates. We show that while countries may be far from their steady state, conditional convergence plays a minor role compared to the other two factors in explaining the development gap between poor and rich countries. One implication is that international financial integration can equalize the marginal return of capital across countries without closing the large gaps in productivity and income per capita between poor and rich nations. It is this implication of the "neoclassical revival" in growth economics that we quantify in this paper.

The paper is structured as follows. Section 2 presents results based on a very stylized neoclassical model. Section 3 presents an extension of the model with endogenous human capital accumulation and various distortions, and interprets our results in the context of a decomposition of world inequality in output per capita. Section 4 concludes with a discussion of the implications of this paper for future research.

\section{A Simple Experiment}

Consider a small Ramsey-Cass-Koopman (RKC) economy that can accumulate physical capital using the savings of its residents and/or by attracting capital from abroad. The country is small relative to the rest of the world in the well-defined sense that the capital account regime has no impact on the world return on capital. Our 'experiment' assesses the benefits of international financial integration for this economy by comparing two extreme cases: a state of complete financial autarky in which the country has to rely purely on domestic savings, and a state of perfect financial integration in which the country can import or export capital at the (given) world interest rate.

We assume that there are no impediments to financial flows under financial integration. This maximizes the welfare benefits from integration, since capital movements will fully and immediately arbitrage away any difference in marginal returns to capital. In other words, financial integration can potentially result in immediate and massive capital flows from a capital-abundant rest of the world to a capital-scarce domestic economy. While the associated dynamics are trivial, this represents, we believe, a simple and transparent case where the gains from international financial integration are potentially large.

Because of its theoretical simplicity, this experiment provides a useful benchmark to start with. The next section will incorporate the insights of the recent literature on convergence and growth in an international perspective, to obtain a more realistic measure of the benefits of international financial integration for a large sample of emerging economies. As we will see, our results are surprisingly robusts to these extensions.

\subsection{The Model}

We consider a world with one homogeneous good and a number of countries. In this world, we focus on a subset of small less-developed countries that may or not open their capital account. Time is discrete and there is no uncertainty. The population grows at an exogenous 
rate $n: N_{t}=n^{t} N_{0}$ that is country specific. The population of each country can be viewed as a large family that maximizes the welfare function

$$
U_{t}=\sum_{s=0}^{\infty} \beta^{s} N_{t+s} u\left(c_{t+s}\right),
$$

where $c_{t}$ is consumption per capita and $u(c) \equiv c^{1-\gamma} /(1-\gamma)$ is a constant relative risk aversion (CRRA) instantaneous utility function with coefficient $\gamma>0$. In the case where $\gamma=1$, the utility function is $u(c)=\ln (c)$.

The domestic economy produces the homogeneous good according to the Cobb-Douglas production function

$$
Y_{t}=K_{t}^{\alpha}\left(A_{t} L_{t}\right)^{1-\alpha},
$$

where $K_{t}$ denotes the stock of domestic capital, $L_{t}$ is labor supply and $A_{t}$ is a laboraugmenting measure of productivity. Labor supply is exogenous and proportional to population $\left(L_{t}=N_{t}\right)$. Factor markets are perfectly competitive. Labor productivity grows at a gross rate $g_{t} \equiv A_{t} / A_{t-1}$, which may differ across countries in the short-run but converges towards the same value for all countries ${ }^{8}$

$$
\lim _{t \rightarrow+\infty} g_{t}=g^{*}
$$

This is a common assumption in the empirical growth literature (Mankiw et al. (1992)). ${ }^{9}$ The common asymptotic growth rate $g^{*}$ reflects the advancement of knowledge, which should not be country specific in the long run. If growth rates of productivity differed permanently across countries, the world income distribution would diverge without bounds and the country or region with the highest long-run growth rate would overtake world output. Some mechanism, such as innovation and technology transfers, must constrain the tendency toward infinite divergence (Eaton and Kortum (1999); Parente and Prescott (2000)).

However, countries could differ in their growth rate of productivity in the short run, or in their levels of productivity $A$ in the long-run. Differences in productivity growth underlie recent 'growth miracles'. Differences in productivity levels reflect, as Mankiw et al. (1992) mention, 'not just technology but resource endowments, climate, institutions, and so on' (p.411). Hall and Jones (1999) ascribe these differences in productivity levels to differences in institutions and government policies, which they call 'social infrastructure'.

Under financial autarky each country accumulates capital domestically. The neoclassical framework predicts that the economy will converge towards a balanced growth in which capital, output and consumption per capita asymptotically grow at the same rate as productivity. We denote with tildes the variables normalized by the level of productivity, i.e. $\tilde{x}_{t}=x_{t} / A_{t}$. It follows from the Euler equation for consumption, $u^{\prime}\left(c_{t}\right)=\beta R_{t+1} u^{\prime}\left(c_{t+1}\right)$ that

$$
\tilde{c}_{t}=\left(\beta R_{t+1}\right)^{-1 / \gamma} g_{t+1} \tilde{c}_{t+1}
$$

\footnotetext{
${ }^{8}$ We assume further that $\beta n g^{*(1-\gamma)}<1$ so that the utility is well defined.

${ }^{9}$ The literature often adopts the stronger assumption that the growth rate of productivity is the same for all countries and at all times, i.e. $g_{t}=g^{*}$.
} 
so that in the long-run the return on domestic saving is given by

$$
R^{*}=g^{* \gamma} / \beta .
$$

$R^{*}$, the natural level of the gross rate of interest, is the same for all countries.

Taking the limit of the first-order condition for capital $R_{t}=\alpha \tilde{k}_{t}^{\alpha-1}+1-\delta_{k}$ (where $\delta_{k}$ is the depreciation rate of capital) gives the asymptotic level of productivity-adjusted capital

$$
\lim _{t \rightarrow+\infty} \tilde{k}_{t}=\tilde{k}^{*}=\left(\frac{\alpha}{R^{*}+\delta_{k}-1}\right)^{1 / 1-\alpha},
$$

which is also the same for all countries.

Under financial integration domestic agents can lend or borrow at the gross world interest rate. We assume that the rest of the world is composed of developed countries that have already achieved their steady state. Under that assumption, the world interest rate is equal to the natural gross rate of interest, $R^{*}$, and financial integration does not 'tilt' permanently consumption profiles. ${ }^{10}$ This assumption has one important implication. The long-run levels of capital and output per capita are the same under autarky and financial integration. These levels may differ across countries because of persistent differences in productivity levels, but they are not affected by the capital account regime. The effect of integration is to accelerate the country's convergence towards a steady growth path that is determined by other factors.

Under financial integration the path of the economy is as follows. First, the Euler equation $c_{t}=\left(\beta R^{*}\right)^{-1 / \gamma} c_{t+1}$ implies that domestic consumption per capita grows at rate $g^{*}$ as soon as the country is financially integrated. Second, the first-order equation for capital implies that $\tilde{k}_{t}$ jumps immediately to its long-run level $\tilde{k}^{*}$. Let us assume that domestic residents can choose the international allocation of domestic wealth $k_{0}$ at time 0 . The consumption level then results from the family's intertemporal budget constraint:

$$
\sum_{t=0}^{\infty}\left(\frac{n}{R^{*}}\right)^{t} c_{t}=R^{*} k_{0}+\sum_{t=0}^{\infty}\left(\frac{n}{R^{*}}\right)^{t} w_{t}
$$

where $w_{t}=(1-\alpha) A_{t} \tilde{k}^{* \alpha}$ is the real wage received by the representative family member at time $t$. It follows that $c_{0}$ is given by

$$
c_{0}=\left(R^{*}-n g^{*}\right) k_{0}+(1-\alpha) \tilde{k}^{* \alpha}\left(1-\frac{n g^{*}}{R^{*}}\right) \sum_{t=0}^{+\infty}\left(\frac{n}{R^{*}}\right)^{t} A_{t} .
$$

We measure the gains from international financial integration as follows. Let us denote by $U_{\text {aut }}$ and $U_{\text {int }}$ the domestic welfare at time 0 under financial autarky and financial integration respectively. The welfare under autarky has no closed-form expression in general, and must be computed by solving numerically for the saddle-point stable equilibrium. By contrast,

\footnotetext{
${ }^{10}$ We believe that it would not be very appealing to assume that the benefits of international financial integration come from intrinsic and permanent differences in the natural rate of interest between countries.
} 
since under financial integration consumption per capita is increasing at the constant rate $g^{*}$, one can derive a closed form expression for $U_{i n t}$

$$
U_{i n t}=N_{0} \frac{R^{*}}{R^{*}-n g^{*}} \frac{c_{0}^{1-\gamma}}{1-\gamma},
$$

where $c_{0}$ comes from the intertemporal budget constraint (6).

By the first welfare theorem we know that domestic welfare is higher under financial integration than under autarky. In the following discussions, we report the Hicksian equivalent variation $\mu$, defined as the percentage increase in the country's consumption that brings domestic welfare under autarky up to its level under integration:

$$
\mu=\left(\frac{U_{\text {int }}}{U_{\text {aut }}}\right)^{\frac{1}{1-\gamma}}-1
$$

if $\gamma \neq 1$, and $\mu=\exp \left((1-n \beta)\left(U_{\text {int }}-U_{\text {aut }}\right) / N_{0}\right)-1$ if $\gamma=1$.

\subsection{Calibration and Results}

We estimate the welfare gains of financial integration for 82 non-OECD countries with annual data in $1995 .{ }^{11}$ Some parameters are common to all countries while others are countryspecific. The common parameters are given in Table 1 . We set $g^{*}=1.012$ in line with long run multifactor productivity growth in the U.S. While the assumption that the capital share is constant across countries is certainly too strong, recent estimates by Gollin (1998) suggest that the Cobb-Douglas assumption is roughly appropriate, with an estimated capital share between 0.2 and 0.4. Accordingly we set $\alpha=0.3$. We also assume a common rate of depreciation of physical capital, equal to $6 \%$ per annum. With these assumptions, the world real interest rate is equal to $R^{*}=1.0542$ and the - common- steady state capital-output ratio $k^{*} / y^{*}$ is equal to 2.63 .

Each country is characterized by a constant population growth rate $n$, an initial level of capital per capita $k_{0}$, and a productivity path $\left(A_{t}\right)_{t \geq 0}$. We measure $n$ as the average rate of growth of the working age population between 1985 and 1995, where working age is defined as 15 to 64 years old. Data on total population and on the fraction of the population of age 15-64 is obtained from the 2002 World Bank Development Indicators.

We construct measures of the initial capital stock using data from the Heston, Summers and Aten (2002) Penn World Tables, Mark 6.1 (PWT) using investment rates and a perpetual

\footnotetext{
${ }^{11}$ The selection is based on OECD membership at the beginning of the time period, so our sample includes three current OECD members, Mexico, South Korea and Turkey. The 82 countries are Algeria, Angola, Argentina, Bangladesh, Barbados, Benin, Bolivia, Botswana, Brazil, Burkina Faso, Burundi, Cameroon, Cape Verde, Central African Republic, Chad, Chile, China, Colombia, Comoros, Democratic Republic of Congo, Republic of Congo, Costa Rica, Cote D'ivoire, Cyprus, Dominican Republic, Ecuador, Egypt, El Salvador, Ethiopia, Fiji, Gabon, Ghana, Guatemala, Guinea, Guinea-Bissau, Guyana, Honduras, Hong Kong, India, Indonesia, Iran, Israel, Jamaica, Lesotho, Madagascar, Malawi, Malaysia, Mali, Mauritania, Mauritius, Mexico, Morocco, Mozambique, Nepal, Nicaragua, Niger, Nigeria, Pakistan, Panama, Papua New Guinea, Paraguay, Peru, Philippines, Rwanda, Senegal, Sierra Leone, Singapore, South Africa, South Korea, Sri Lanka, Syria, Tanzania, Thailand, Togo, Trinidad \& Tobago, Tunisia, Turkey, Uganda, Uruguay, Venezuela, Zambia and Zimbabwe.
} 


\begin{tabular}{ccccc}
\hline$\beta$ & $\gamma$ & $\alpha$ & $\delta_{k}$ & $g^{*}$ \\
0.96 & 1 & 0.3 & 0.06 & 1.012 \\
\hline
\end{tabular}

Table 1: Common parameters

inventory method like in Bernanke and Gürkaynak (2001). ${ }^{12}$ The productivity level of a given country in a given year 0 can then be derived from its capital stock, its output and the CobbDouglas relationship $y_{0}=A_{0}^{1-\alpha} k_{0}^{\alpha}$. One can then compute for each country the ratio of the capital installed in year 0 to the capital level that would prevail under perfect financial integration, $k_{0} /\left(A_{0} \widetilde{k}^{*}\right)$. This capital ratio is a measure of the country's capital abundance. It is higher than 1 for the countries that export capital under integration, and lower than 1 for the countries that import capital.

Table 2 gives population weighted averages of the capital ratios for various subsets of our sample of countries defined on a regional or income level basis. ${ }^{13}$ For comparison, we also report the capital ratio for 22 OECD countries (last row). ${ }^{14}$ There is no significant capital gap for OECD countries, a result consistent with our assumption that emerging countries can borrow and lend internationally at rate $R^{*}$ from industrialized countries.

Non-OECD countries exhibit a significant capital deficit, with capital ratios averaging 0.41 , and increasing steadily with income level. While that average masks substantial heterogeneity -with capital ratios as low as 0.03 for Uganda, and as high as 1.37 for Singapore, most developing countries are still far away from their steady state. A decomposition by regions reveals that Africa and Asia are furthest away from steady state, compared to Latin America. Finally, since China and India together represent $52.8 \%$ of the population in our sample, the table also reports separately the results for Non-OECD countries outside these two countries.

In order to compute countries' welfare gains from integration in year 0 we need the path of future productivities $\left(A_{t}\right)_{t \geq 0}$. We start with the simple assumption that productivity grows at the long-run rate $g^{*}$ from year 0 onwards (i.e., that there is no productivity catchup relative to the U.S. after year 0 ).

Table 3 shows the benefits of international financial integration for the same country groupings as in table 2 . While the gains for individual countries can be substantial (with a maximum of 8.03 percent for Mozambique), the average gain per capita are much smaller, of the order of 1.24 percent of autarky consumption. These gains are decreasing with income, as expected, since richer countries are also closer to steady state. The results are similar whether China and India are included in the sample or not.

It is important to emphasize that we find small welfare gains despite, as table 2 makes

\footnotetext{
${ }^{12}$ Hsieh and Klenow (2003) and Cohen and Soto (2002) argue that one should construct capital stocks using nominal investment rates instead of PPP investment rate, since poorer countries face systematically higher relative prices for investment goods. Since nominal investment rates are higher, this yields comparatively smaller capital gaps, and hence smaller welfare gains. Using nominal investment rates, we estimate an average capital ratio of 0.75 . (The results are available upon request to the authors.)

${ }^{13}$ We use the World Bank income classification. See http://www.worldbank.org/data/countryclass/classgroups.htm

${ }^{14}$ The 22 OECD countries are Australia, Austria, Belgium, Canada, Denmark, Finland, France, Greece, Iceland, Ireland, Italy, Japan, Luxembourg, the Netherlands, New-Zealand, Norway, Portugal, Spain, Sweden, Switzerland, the United Kingdom and the USA.
} 


\begin{tabular}{lcc}
\hline & \multicolumn{2}{c}{ Capital ratio } \\
& $k_{0} / k^{*}$ & Obs. \\
\cline { 2 - 3 } Non-OECD countries & 0.41 & 82 \\
Low Income & 0.29 & 38 \\
Lower Middle Income & 0.46 & 25 \\
Upper Middle Income & 0.68 & 14 \\
High Income (non-OECD) & 1.04 & 5 \\
Africa & & \\
Latin-America & 0.34 & 44 \\
Asia & 0.63 & 22 \\
except China and India & 0.40 & 16 \\
China and India & 0.46 & 80 \\
OECD & 0.36 & 2 \\
\hline
\end{tabular}

Table 2: Capital scarcity. Population weighted average. Year is 1995.

\begin{tabular}{|c|c|c|c|c|c|}
\hline & \multicolumn{5}{|c|}{ Equivalent Variation, $\mu$ (percent) } \\
\hline & mean & $\min$ & $\max$ & s.d. & Obs. \\
\hline Non-OECD countries & 1.24 & 0 & 8.03 & 0.87 & 82 \\
\hline Low Income & 1.71 & 0.01 & 8.03 & 0.92 & 38 \\
\hline Lower Middle Income & 0.98 & 0 & 2.99 & 0.54 & 25 \\
\hline Upper Middle Income & 0.23 & 0.09 & 2.10 & 0.28 & 14 \\
\hline High Income (non OECD) & 0.05 & 0.01 & 0.32 & 0.09 & 5 \\
\hline Africa & 1.65 & 0.01 & 8.03 & 1.60 & 44 \\
\hline Asia & 1.27 & 0 & 1.81 & 0.51 & 16 \\
\hline Latin-America & 0.40 & 0.09 & 1.95 & 0.51 & 22 \\
\hline except China and India & 1.06 & 0.00 & 8.03 & 1.19 & 80 \\
\hline China and India & 1.39 & 1.08 & 1.79 & 0.50 & 2 \\
\hline
\end{tabular}

Table 3: The benefits of international financial integration.

The table reports the population weighted average of the equivalent variation $\mu$. Year is 1995 .

clear, substantial initial capital gaps. Figure 1 reports the equivalent variation as a function of the initial capital ratio $k_{0} / k^{*}$ for all non-OECD countries in our sample. The solid line represents the theoretical welfare gains for a country with the same population growth rate as the United States, as a function of its initial capital ratio. ${ }^{15}$ This graph delivers a stark message: since the curve is very flat around 1, a country must be very scarce or very abundant in capital to significantly benefit from international financial integration. The capital ratio must fall below 0.36 or exceeds 2 for the gains from integration to exceed 2 percent. The same is true for the developing countries in the sample: only countries very far from steady state -typically below 0.2 - enjoy significant gains from financial integration. Such countries represent less than 4 percent of the aggregate population in our sample. ${ }^{16}$

\footnotetext{
${ }^{15}$ Countries are below the curve because they generally have a higher population growth rate than the United States.

${ }^{16}$ The 11 countries, all African, with gains in excess of 2 percent are: Burundi, Central African Republic, Chad, Egypt, Ethiopia, Madagascar, Mauritius, Mozambique, Rwanda, Sierra Leone and Uganda.
} 


\subsection{Is it large? Some Comparisons.}

It is important to establish relevant points of comparisons. After all, a welfare gain of $1.24 \%$ of consumption would be considered quite high in the empirical public finance literature establishing the incidence of taxes (Mendoza and Tesar (1998)). Another point of comparison comes from the literature on the benefits of smoothing economic fluctuations. Although our estimates are substantially larger than the benefits for developed economies, estimated to represent a fraction of a percentage point (Lucas (1987)), they are of the same order of magnitude as the benefits obtained by Pallage and Robe (2003) for less developed economies and aid-dependent countries.

This section proposes two other points of comparison. First, we present estimates of the welfare gains from a productivity catch-up. Then, we evaluate the benefits of international financial integration on output growth and convergence.

\subsubsection{The benefit of a productivity take-off}

We now revisit the assumption that relative productivity remains constant. Clearly, this is an extreme and unrealistic assumption. Figure 2 reports the change in relative productivity $A_{0} / A_{0}^{\text {us }}$ for non-OECD countries between 1960 and 1995. While many developing countries fell behind in terms of relative productivity, a number of countries - such as Hong-Kong, Singapore, Cyprus, Israel or Mauritius - experienced a drastic improvement in productivity. These countries increased their productivity relative to the United States by more than 25 percent over that time period, and by as much as 78 percent for Hong Kong. We now evaluate the welfare gains from such productivity catch-up.

More specifically, assume that productivity converges partly toward the world technology frontier (here, the U.S.) according to

$$
\frac{A_{t}}{A_{t}^{u s}}=\frac{A_{0}}{A_{0}^{u s}}+x \frac{t}{35}\left(1-\frac{A_{0}}{A_{0}^{u s}}\right)
$$

in the first thirty-five years $(t \leq 35)$, after which the growth rate in productivity goes back to the U.S. level. The variable $x$ represents the convergence in productivity expressed as a fraction of the original productivity gap. The case $x=0$ corresponds to no-convergence, and $x=1$ corresponds to full convergence in 35 years.

Table 4 reports relative productivity in 1995, as well as the welfare gains from a productivity catch-up ranging between 25 and 100 percent under financial autarky. Emerging countries are much less productive than the U.S., with an average relative productivity of 0.14, increasing with income. In that context, we find that the gains from a productivity catch-up are extremely large. A 25 percent reduction in the productivity gap yields welfare gains of 135 percent on average. A full catch-up would yield the equivalent of an almost six fold increase in consumption! 


\begin{tabular}{|c|c|c|c|c|c|c|}
\hline \multicolumn{2}{|c|}{ Equivalent Variation, $\mu$ (percent) } & \multicolumn{5}{|c|}{$\begin{array}{l}\text { productivity catch-up } \\
x \text { (percent) }\end{array}$} \\
\hline & $A_{0} / A_{0}^{\text {us }}$ & 25 & 50 & 75 & 100 & Obs. \\
\hline Non-OECD countries & 0.14 & 135 & 258 & 377 & 494 & 82 \\
\hline Low Income & 0.10 & 190 & 365 & 534 & 701 & 38 \\
\hline Lower Middle Income & 0.14 & 99 & 188 & 273 & 356 & 25 \\
\hline Upper Middle Income & 0.29 & 46 & 88 & 130 & 171 & 14 \\
\hline High Income (non OECD) & 0.48 & 19 & 37 & 55 & 72 & 5 \\
\hline Africa & 0.12 & 260 & 504 & 742 & 979 & 44 \\
\hline Asia & 0.26 & 116 & 222 & 323 & 421 & 16 \\
\hline Latin-America & 0.12 & 55 & 106 & 156 & 205 & 22 \\
\hline except China and India & 0.18 & 150 & 291 & 428 & 563 & 80 \\
\hline China and India & 0.11 & 120 & 229 & 332 & 433 & 2 \\
\hline
\end{tabular}

Table 4: The benefits of a productivity catch-up.

The table reports the population weighted average of the equivalent variation $\mu$ for various values of the productivity catch-up. Year is 1995.

\subsubsection{A different metric: output growth and convergence}

As mentioned in the introduction, the empirical literature on the benefits of capital account liberalization often focuses on domestic output growth. We can use our simple model to revisit this issue. Table 5 reports the increase in output growth predicted by the model at various horizons. The large increase in output growth at a one-year horizon reflects the absence of any friction in the capital market. More realistically, the table shows that at the 5 -year horizon the gain in output growth can be substantial, in excess of 2.5 percent per year on average. The empirical literature reports somewhat smaller gains. For instance, Bekaert et al. (2002) find a 1 percent higher growth rate of output after 5 years, following an equity market liberalization. In light of our welfare calculations, these growth improvements do not necessarily have major welfare implications.

The preceding table emphasizes that the impact on output growth can be substantial, especially at short horizons. Yet, the overall impact on intertemporal output may be relatively small. We illustrate this point in Figure 3. Panel A represents the impact of full international financial integration on the present discounted value of output. The horizontal axis represents the present discounted value of domestic output per capita under autarky (in thousand of international 1995 dollars) while the vertical axis represents the present discounted value of domestic output per capita under financial integration. For comparison, the figure also includes a 45 degree line. The vertical distance between each point and the 45 degree line measures the permanent output gains from financial integration. As we can see from the figure, for most countries, the output gains are hardly discernible at all. For the sake of comparison, Panel B of figure 3 shows the results under a domestic productivity catchup of 25,50 or $75 \%$, according to equation (9). By contrast with international financial integration, a productivity take-off has a first-order effect in reducing international differences in permanent income per capita. 


\begin{tabular}{|c|c|c|c|c|}
\hline \multicolumn{5}{|c|}{$\begin{array}{c}\text { Change in domestic output growth (percent, per annum) } \\
\text { Horizon }\end{array}$} \\
\hline & 1 & 5 & 10 & Obs. \\
\hline Non-OECD countries & 30.03 & 2.83 & 0.65 & 82 \\
\hline Low Income & 39.59 & 3.59 & 0.81 & 38 \\
\hline Lower Middle Income & 24.75 & 2.46 & 0.58 & 25 \\
\hline Upper Middle Income & 11.63 & 1.26 & 0.31 & 14 \\
\hline High Income & -0.78 & -0.10 & -0.03 & 5 \\
\hline Africa & 41.29 & 3.52 & 0.78 & 44 \\
\hline Asia & 29.57 & 2.87 & 0.66 & 16 \\
\hline Latin-America & 15.50 & 1.59 & 0.38 & 22 \\
\hline except China and India & 28.88 & 2.64 & 0.58 & 80 \\
\hline China and India & 31.07 & 3.02 & 0.70 & 2 \\
\hline
\end{tabular}

Table 5: Impact on Growth.

The table reports the population weighted change in domestic output growth following financial integration. Year is 1995

\subsection{Intuition and Robustness}

The welfare gains from a technological catch-up dominate those from international financial integration by an order of magnitude. That the gains from a catch-up are large is not too surprising once it is realized that a catch-up of 25 percent more than doubles the productivity (and output per capita) of most non-OECD countries in the long-run. Rather, the surprise is that the gains from international financial integration are so low, given the very large size of capital inflows predicted by the model when the typical non-OECD country opens itself to foreign capital. This section provides the intuition for why the gains from international financial integration are low.

To build up our intuition, we derive a simple expression for the welfare gain from a marginal increase in international financial integration. Let us assume that in a capitalscarce country, a central planner authorizes the entry of a marginal amount of foreign capital $d \kappa_{t+1}$ at time $t$ (using quantitative capital controls, say). This increases the equilibrium real wage and decreases the return on domestic savings. By the envelope theorem, we know that the net welfare gain from the marginal capital inflow is the same as if $d \kappa_{t+1}$ were invested at time $t$ and the resulting increase in domestic net income were consumed in period $t+1$. The marginal increase in period $t+1$ domestic net income is $d y_{t+1}-R^{*} d \kappa_{t+1}$, where the increase in domestic output $d y_{t+1}$ is equal to the marginal return to capital, $R_{t+1}$, times the capital inflows, $d \kappa_{t+1}$. Hence, the welfare gain at time $t+1$ can be written ${ }^{17}$

$$
d U_{t+1}=u^{\prime}\left(c_{t+1}\right)\left(R_{t+1}-R^{*}\right) d \kappa_{t+1} .
$$

The welfare gain from a small capital inflow in terms of current consumption is equal to the return differential between the country and the rest of the world times the capital inflow.

One can view financial integration at time 0 as the result of an incremental process in which the social planner continuously relaxes the capital controls in all subsequent periods.

\footnotetext{
${ }^{17}$ Population growth is assumed away for simplicity.
} 
Assume that at time 0 all the subsequent authorized capital inflows are increased by a small fraction of consumption, i.e. $d \kappa_{t+1}=c_{t+1} d c / c$. With log-preferences, the equivalent variation is approximately: ${ }^{18}$

$$
\mu \approx \beta\left(\hat{R}-R^{*}\right) \frac{d c}{c},
$$

where $\hat{R} \equiv(1-\beta) \sum_{0}^{\infty} \beta^{t} R_{t+1}$ represents the permanent value of the domestic interest rate.

Starting from the capital ratio of the average non-OECD country (0.41), the initial domestic return on capital is 15 percent, 10 percent above the world interest rate. But the domestic return converges toward the world interest rate, and the permanent value $\hat{R}$, at 6.9 percent, is only 1.46 percent higher than the world interest rate. Equation (10) then implies that starting from autarky, a marginal capital inflow equal to 1 percent of domestic consumption yields a welfare benefit equivalent to 0.0146 percent of consumption. Thus, the welfare gain for the recipient country is a very small fraction of the face value of the capital inflows.

From that point of view, there is a significant difference between our results and those of the calibrated literature on the welfare effects of trade liberalization. The small welfare gains in that literature - sometimes referred to as the 'Harberger constant' - arise from the elimination of small 'triangular' distortionary losses. Here, the large size of the capital inflows unleashed by financial integration might suggest that the welfare triangle is not small; yet, the welfare losses from the distortion are found to be as small as in the trade literature. The reason has to do with the intertemporal profile of the distortion. By contrast with trade restrictions, the distortion induced by capital account restrictions tend to vanish by itself over time, as countries converge toward the same steady-state level of capital under autarky as under integration. The welfare cost of autarky is determined by the intertemporal level of the distortion, which may be much smaller than the initial level.

The small gains from international financial integration are intuitive, conditional on the return differential predicted by the model. This raises the question of whether this differential is empirically plausible. The model predicts an average marginal return on capital of 15 percent for non-OECD countries in 1995. This seems consistent with some estimates of the return to investment in less developed countries. For example, Isham and Kaufman (1999) find that the average economic rate of return on private projects financed by the World Bank is 14 percent. $^{19}$

Another issue is the speed at which the return differential decreases over time, which is directly related to the conditional speed of convergence toward the steady state. As is well-known, the convergence speed in the benchmark Ramsey model is excessively high. In our model the speed of convergence - measured as the fraction of the output gap that is eliminated every year - is 11.16 percent. This is much larger than the 2-3 percent reported by Barro and Sala-i-Martin (1992), and inside the 8-13 percent range estimated by Caselli,

\footnotetext{
${ }^{18}$ See appendix A.

${ }^{19}$ Banerjee and Duflo (2002)'s study of the Indian credit market reports much larger returns that are left unexploited because of credit rationing. However, credit rationing will apply to foreign investors in the same way as domestic lenders, unless one has a theory of how international financial integration reduces domestic financial frictions. This is indeed an important question - as we argue at the end of the paper - but one outside the scope of the neoclassical framework.
} 


\begin{tabular}{|c|c|c|c|c|c|}
\hline \multicolumn{6}{|c|}{ Equivalent Variation, $\mu$ (percent) } \\
\hline & \multicolumn{4}{|c|}{$\gamma$} & \multirow[b]{2}{*}{ Obs. } \\
\hline & 1 & 3 & 5 & 10 & \\
\hline Non-OECD countries & 1.24 & 2.49 & 2.43 & 2.14 & 82 \\
\hline Low Income & 1.71 & 3.99 & 4.15 & 2.18 & 38 \\
\hline Lower Middle Income & 0.98 & 1.45 & 1.04 & 1.31 & 25 \\
\hline Upper Middle Income & 0.23 & 0.11 & 0.25 & 4.22 & 14 \\
\hline High Income (non OECD) & 0.05 & 0.65 & 2.57 & 12.51 & 5 \\
\hline Africa & 1.65 & 5.01 & 6.31 & 5.75 & 44 \\
\hline Asia & 1.27 & 2.17 & 1.75 & 1.00 & 16 \\
\hline Latin-America & 0.40 & 0.58 & 0.67 & 3.74 & 22 \\
\hline except China and India & 1.06 & 2.72 & 3.21 & 4.04 & 80 \\
\hline China and India & 1.39 & 2.28 & 1.72 & 0.43 & 2 \\
\hline
\end{tabular}

Table 6: Intertemporal Elasticity of Substitution.

The table reports the population weighted average of the equivalent variation $\mu$ for various values of the intertemporal elasticity of substitution $1 / \gamma$

Esquivel and Lefort (1996), who correct some biases in earlier estimation methods. Given that the model's speed of convergence is close to the highest estimates obtained in the literature, it would be reassuring to test the robustness of our results to modifications of the model that reduce the speed of convergence. ${ }^{20}$ We do this in the next section by introducing human capital. ${ }^{21}$

Finally, we close this section with a robustness test. Our results so far are derived under log preferences. One could argue that lower elasticities of intertemporal substitution would increase the gains from financial integration by lowering welfare under autarky. However a smaller elasticity of intertemporal substitution also makes households more reluctant to accumulate capital. This increases the long run natural world interest rate $R^{*}=g^{* \gamma} / \beta$, lowers our estimates of the capital gap, and consequently, the potential gains from financial integration. ${ }^{22}$ Table 6 presents results for values of $\gamma$ between 3 and 10. We find that the welfare gains increase on average, from 1.24 to 2.49 percent of consumption when $\gamma=3$, then decrease as the second effect dominates.

\footnotetext{
${ }^{20}$ To see by how much our results could be affected by the speed of convergence, consider the extreme case where this speed is zero (i.e. if the return differential remained at its initial level forever). Then the permanent value of the return differential would jump from 1.46 percent to 10 percent, a seven-fold increase. This is large in relative terms, but note that a seven-fold increase would still leave the gains from integration much below those from a productivity catch-up.

${ }^{21}$ Of course, this is not the only way convergence could be slowed down in our model. For example, we could introduce an external credit constraint as in Barro et al. (1995). This would reduce the speed of convergence conditional on integration, and so thegains from integration. Alternatively, the convergence speed could be reduced by introducing adjustment costs in capital accumulation. This would lower the speed of convergence both under autarky and under integration, with an a priori ambiguous impact on the gains from integration.

${ }^{22}$ This puts some discipline on which elasticity of intertemporal substitution one should choose. For instance, with $\gamma=10$, we estimate an unreasonable capital ratio $k_{0} / k^{*}$ of 1.14 for non-OECD countries.
} 


\section{Extending the basic model}

We now augment the model of section 2 in two ways. First, we introduce human capital accumulation. Second, we allow for domestic distortions in the accumulation of physical and human capital.

Human capital is a basic element in growth theory. Differences in educational attainment, or schooling rates translate into more or less productive labor force and have long been described as a key element in cross-country income differences. Microeconomic studies also document significant returns to education (Duflo (2001)). Second, human capital makes the transition dynamics more realistic, both under financial integration - where the dynamics are no longer trivial - and under autarky — where the accumulation of human capital slows down the convergence toward the steady state. Finally, human capital accumulation is a channel through which domestic productivity is endogenous to the capital account regime. Faster accumulation of physical capital could induce faster accumulation of human capital, in particular by increasing the real wage.

The motivation for introducing distortions in the accumulation of physical and human capital is to give a better account of observed cross-country differences in investment rates. The previous section assumed that differences between countries are summarized by their initial level of productivity $A_{0}$ and the growth rate of population $n$. This implies relatively small cross country variations in capital accumulation rates. For instance, the model of the previous section predicts steady-state physical investment rates between 20.8 and 29 percent for non-OECD countries. This is at odds with the data, where average investment rates from 1985 to 1995 range from 2.80 percent (Madagascar) to 41.40 percent (Singapore). Similarly, distortions in the accumulation of human capital allow us to account for observed educational attainments ranging from 0.7 years (Mali) to 10.1 years (South Korea). Easterly, Kremer, Pritchett and Summers (1993) report that accumulation rates for physical and human capital are very persistent across decades.

\subsection{The model}

We assume that the labor employed in production $L_{t}$ is homogenous and has been trained with $E_{t}$ years of schooling, which we will interpret as educational attainment. As a result, the domestic economy produces according to a 'Macro-Mincer' Cobb-Douglas production function:

$$
Y_{t}=K_{t}^{\alpha}\left(A_{t}^{\prime} e^{\phi\left(E_{t}\right)} L_{t}\right)^{1-\alpha}
$$

where $A_{t}^{\prime}$ reflects the exogenous, non-human-capital-related, determinants of productivity. The function $\phi^{\prime}(E)$ represents the marginal return to schooling estimated in a Mincerian wage regression.

Human capital accumulation depends upon the fraction of time devoted to education, $s_{t}$, according to

$$
E_{t+1}=\left(1-\delta_{e}\right) E_{t}+\theta s_{t}
$$

where $\delta_{e}$ is a depreciation rate for human capital and $\theta$ captures the efficiency of the domestic schooling technology and accounts for steady state differences in educational attainment. 
This perpetual inventory specification is consistent with existing empirical work on human capital stocks (see Barro and Lee (1993)). Because the problem is not concave in the level of educational attainment, we must impose bounds on $s$ to avoid corner solutions in which the country invests 100 percent or 0 percent of its time in education. We impose that $0 \leq \underline{s} \leq s \leq \bar{s}<1$. Finally, labor market clearing implies $L_{t}=\left(1-s_{t}\right) N_{t}$.

Investment in domestic capital is implicitly distorted at rate $\tau$, so that the private return to domestic capital is $(1-\tau) R_{t}$. We refer to $\tau$ as the capital wedge. As discussed above, it allows us to match the observed disparity in saving rates across countries. $\tau$ is a shorthand for all the distortions that potentially affect the return to domestic capital: credit market imperfections, taxation, expropriation, bureaucracy, bribery and corruption... Different models would have different implications for the implicit rents generated by the distortion, $z_{t} \equiv \tau R_{t} k_{t}$. For simplicity, we assume that they are rebated in a lump-sum fashion to the representative agent. In this manner, we focus exclusively on the distortive aspects of the capital wedge.

The model with human capital is solved in appendix A in the case where catchup is limited to human capital $\left(A_{t}^{\prime}=A_{0}^{\prime} g^{* t}\right.$ ). The main features of the equilibrium are preserved. Physical and human capital converge to steady state values that are independent of the capital account regime. Human capital converges to a level that depends on the efficiency of the domestic schooling technology (and not on the capital wedge). The investment in human capital is bang-bang under financial integration in the sense that $s=\underline{s}(s=\bar{s})$ if human capital is above (below) its long-run level. It follows that human capital converges to the steady state level in finite time.

To illustrate the effect of human capital accumulation, Figure 4 reports the convergence paths to the steady state for education, consumption, physical and human capital, for an economy calibrated to the U.S. when $k_{0}=0.5 k^{*}$ and $E_{0}=0.6 E^{*} .{ }^{23}$ The convergence trajectories are very different depending upon the capital account regime. In this example, the country has initially relatively more human than physical capital. Under autarky, it is optimal to concentrate on accumulating physical capital. Hence the schooling rate $s$ and consumption $c$ are low, while capital accumulates rapidly. Under financial integration, by contrast, it is always optimal to accumulate human capital as rapidly as possible. This implies a smaller rate of accumulation of physical capital until $s$ reaches its steady state. Second, convergence - although not instantaneous - is much more rapid under financial integration. The integrated economy reaches its steady state in about fifteen years.

Figure 4 illustrates that financial opening need not be associated with large capital inflows, at least initially. In this particular example, there are no capital inflows or outflows at time 0 . On the other hand, when human capital reaches its steady state, a large quantity of labor becomes available for production and attracts correspondingly large amounts of capital. The figure also illustrates that long run consumption under integration $c_{0}$ is lower than steady state consumption under autarky $c^{*} \cdot{ }^{24}$

${ }^{23}$ The parameters are set to the U.S. economy: $\tau=0.66 \% ; \theta=1.28 ; n=0.73 \% ; \delta_{e}=2.76 \%$. These values imply $\tilde{k}^{*}=9.62, s^{*}=0.29$ and $E^{*}=13.49$. We also impose $\underline{s}=0$ and $\bar{s}=0.5$.

${ }^{24}$ See appendix $\mathrm{A}$ for a closed-form expression for $c^{*}-c_{0}$ as well as some interpretation. 


\subsection{Calibration and results}

The details of the calibration are presented in appendix B. We follow Hall and Jones (1999), and adopt a piecewise linear representation of the returns to schooling consistent with the empirical evidence in Psacharopoulos (1994). We construct estimates of the steady state and initial human capital, by following closely the perpetual inventory method of Barro and Lee (1993). Briefly, we construct a measure of total educational attainment for people over age 25 using data on durations and educational attainment rates of primary, secondary and higher schooling. This provides a stock measure $E_{t}$, every five years from 1960 to 2000. We assume further that $\underline{s}=0$ and $\bar{s}=0.5{ }^{25}$

The capital wedge $\tau$ and the schooling efficiency $\theta$ were calibrated for each country as follows. We construct the conditional steady state of each country by projecting forward the observed enrollment and investment rates. We then infer the values of $\tau$ and $\theta$ by fitting the steady-state accumulation rates predicted by the model to the country's conditional steady state. This assigns some of the differences in long-run output per capita to differences in physical and human capital accumulation rates. As discussed above, we see as empirically plausible that countries have different long-run accumulation rates. Therefore, this case constitutes our benchmark.

For the sake of the comparison, we also look at the results under the assumption that there are no distortions, i.e. the capital wedge $\tau$ is equal to zero and the schooling efficiency $\theta$ is the same as in the U.S. in all countries. This assumes that differences in long run output per capital are solely explained by differences in productivity $A^{\prime}$ and population growth $n$. It corresponds more closely to the assumptions of the previous section with physical capital only and allows us to check the plausibility of our results under - admittedly extremeassumptions.

Table 7 reports relative human capital, $E_{0} / E^{*}$, as well as the projected steady-state attainment level $E^{*}$ and the efficiency of the schooling system relative to the U.S. while table 8 reports the relative physical capital $k_{0} / k^{*}$ together with the estimated capital wedge $\tau .^{26}$

In the presence of distortions, we find that countries are close to their steady state, with an educational attainment ratio of 1.03 and a capital ratio of $0.68 .{ }^{27}$ The average relative education parameter is 0.61 , much below one, while the capital wedge is moderate but positive, equal to $7.6 \%$. The capital wedge is negative for the high income countries because our method interprets the very large average saving rates of countries like Singapore (41\%) and Korea (37\%) as evidence of an implicit subsidy to investment $(-4.7 \%$. and $-4 . \%$

\footnotetext{
${ }^{25}$ This assumption influences the speed of convergence toward the steady state under financial integration. The assumption that $\bar{s}=0.5$ ensures that no country is constrained in steady state.

${ }^{26}$ The sample contains 60 countries. The following 22 countries do not have detailed educational data and were dropped: Angola, Burkina Faso, Burundi, Cape Verde, Chad, Comoros, Democratic Republic Of Congo, Cote D'ivoire, Ethiopia, Gabon, Ghana, Guinea, Guinea-Bissau, Madagascar, Mauritania, Morocco, Nigeria, Pakistan, Sri Lanka, Tanzania, Thailand and Zimbabwe.

${ }^{27}$ Such a high human capital ratio is partly driven by China and India, two very populous countries that undertook significant education programs, and are estimated to be above steady state. Removing these countries, the average human capital ratio drops to 0.68 .
} 


\begin{tabular}{|c|c|c|c|c|c|}
\hline \multirow[b]{2}{*}{ Steady State: } & \multirow{2}{*}{$\begin{array}{c}\text { Relative } \\
\text { Efficiency } \\
\theta / \theta^{\text {us }} \\
\text { benchmark }\end{array}$} & \multirow{2}{*}{$\begin{array}{c}\text { Steady State } \\
\text { Attainment } \\
E^{*} \\
\text { benchmark }\end{array}$} & Attain & ent Ratio & \multirow[t]{2}{*}{ Obs. } \\
\hline & & & benchmark & no distortion & \\
\hline Non-OECD countries & 0.61 & 5.08 & 1.03 & 0.35 & 60 \\
\hline Low Income & 0.49 & 4.16 & 0.95 & 0.27 & 21 \\
\hline Lower Middle Income & 0.66 & 5.11 & 1.17 & 0.40 & 21 \\
\hline Upper Middle Income & 0.78 & 7.47 & 0.75 & 0.42 & 13 \\
\hline High Income (non-OECD) & 1.01 & 11.20 & 0.88 & 0.72 & 5 \\
\hline Africa & 0.76 & 6.44 & 0.64 & 0.29 & 25 \\
\hline Latin-America & 0.75 & 7.08 & 0.76 & 0.40 & 22 \\
\hline Asia & 0.57 & 4.56 & 1.13 & 0.36 & 13 \\
\hline except China and India & 0.94 & 6.95 & 0.68 & 0.34 & 58 \\
\hline China and India & 0.69 & 3.90 & 1.26 & 0.36 & 2 \\
\hline
\end{tabular}

Table 7: Human Capital parameters and Estimates. Population weighted averages. Year is 1995.

respectively). Conversely, Mozambique and Uganda, countries with the lowest average saving rates $(2.9 \%$ and $3 \%$ respectively) are associated with a large capital wedge (40\% and $46 \%$ respectively).

It is noteworthy that in spite of the distortions, the capital ratio, at 0.68 , remains low on average. Our results do not indicate, as is sometimes presumed, that emerging economies will not benefit from financial integration because they are very close to their steady state. ${ }^{28}$ Unsurprisingly, countries are found to be even further below their steady states if the latter are not lowered by distortions - with an average educational attainment ratio of 0.35 and physical capital ratio of 0.27 .

Human capital accumulation slows down convergence toward the steady state. Figure 5 presents convergence paths for output relative to steady state in the simple model of section 2 (black solid line) as well as the models of section 3 with and without domestic distortions (dashed and blue solid line respectively). To construct this figure, we set initial physical and human capital so that the initial output ratio is $0.9{ }^{29}$ It is apparent that convergence is much slower with human capital accumulation, with or without distortions. The speed of convergence decreases from 11.16 percent in the model without human capital to 3.67 and 3.21 percent respectively in the model with and without domestic distortions. These convergence speed are reasonably close to the lower range of existing empirical estimates (Barro and Sala-i-Martin (1992)).

Table 9 reports the welfare gains. The benchmark case yields welfare gains that are very similar to the simple experiment of the previous section. Non-OECD economies benefit, on

\footnotetext{
${ }^{28}$ However, it is interesting to note that Latin America and Africa are above their steady state. These regions are capital-abundant conditional on their productivity and their distortions.

${ }^{29}$ The corresponding initial ratios are respectively: $k_{0} / k^{*}=0.70$ for the model with physical capital only, $k_{0} / k^{*}=E_{0} / E^{*}=0.90$ for the model without distortions, and $k_{0} / k^{*}=E_{0} / E^{*}=0.82$ for the model with distortions.
} 


\begin{tabular}{|c|c|c|c|c|}
\hline Steady State: & $\begin{array}{c}\text { Wedge (\%) } \\
\tau \\
\text { benchmark }\end{array}$ & $\begin{array}{r}\text { Capi } \\
k \\
\text { benchmark }\end{array}$ & $\begin{array}{l}\text { l Ratio } \\
k^{*} \\
\text { no distortion }\end{array}$ & Obs. \\
\hline Non-OECD countries & 7.6 & 0.68 & 0.27 & 60 \\
\hline Low Income & 12.0 & 0.66 & 0.17 & 21 \\
\hline Lower Middle Income & 4.8 & 0.63 & 0.30 & 21 \\
\hline Upper Middle Income & 5.4 & 1.03 & 0.47 & 13 \\
\hline High Income (non-OECD) & -3.2 & 0.54 & 0.83 & 5 \\
\hline Africa & 19.3 & 1.20 & 0.23 & 25 \\
\hline Latin-America & 7.4 & 1.06 & 0.43 & 22 \\
\hline Asia & 6.2 & 0.55 & 0.25 & 13 \\
\hline except China and India & 10.2 & 0.96 & 0.33 & 58 \\
\hline China and India & 6.0 & 0.51 & 0.23 & 2 \\
\hline
\end{tabular}

Table 8: Capital Ratio and Capital Wedge. Population weighted averages. Year is 1995.

average, to the tune of 0.95 percent of consumption from a complete financial liberalization. ${ }^{30}$ The gains from integration are more than five times larger if the distortions are removed (5.51 percent instead of 0.95 percent). This suggests that the two changes we have made to the simple model of section 2 (the accumulation of human capital and the distortions) offset each other. On the one hand, the accumulation of human capital, in and of itself, increases significantly the gains from integration by slowing down convergence and by inducing a catch-up in productivity. On the other hand, the distortions tend to reduce these gains by bringing countries closer to their steady states. It turns out that on balance, the two effects cancel out and the average gain remains about the same as in section 2 . However, the geographic distribution of the gains is different - low income countries now benefit less than lower middle income countries from international financial integration, because they are less efficient in the accumulation of (physical and human) capital.

\subsection{Prosperity and Capital Mobility: Development Accounting}

What are the implications of our analysis for the world income distribution? Our findings indicate that international financial integration, unlike a productivity catch-up, does not significantly reduce the gap between developed and less developed countries. An equivalent interpretation is that transitional convergence explains little of the world income distribution. Consider a country like Togo. According to our calculations, Togo stands to gain $0.19 \%$ of permanent consumption if it opens its capital account completely and foreign capital is free to rush in. But perhaps this should not come as a surprise, once we realize that the gross investment rate in Togo has been only $6.03 \%$ from 1985 to 1995, that the implicit distortion on real returns to capital is $26.9 \%$ and the education efficiency of Togo relative to the U.S.

\footnotetext{
${ }^{30}$ The number for high income non-OECD countries is negative. This is so since the model with distortions does not satisfy the criteria of the first welfare theorem. Countries can be made worse off by international financial integration. Specifically, this happens when countries subsidize capital returns $(\tau<0)$. Capital inflows mean that the subsidy goes to foreign investors.
} 


\begin{tabular}{|c|c|c|c|c|c|}
\hline \multicolumn{6}{|c|}{ Equivalent Variation, $\mu$ (percent) } \\
\hline \multirow[t]{2}{*}{ Steady State: } & \multicolumn{2}{|c|}{ benchmark } & \multicolumn{2}{|c|}{ no distortion } & \multirow[b]{2}{*}{ Obs. } \\
\hline & mean & s.d. & mean & s.d. & \\
\hline Non-OECD countries & 0.95 & 0.65 & 5.51 & 2.52 & 60 \\
\hline Low Income & 0.96 & 0.51 & 7.29 & 2.41 & 21 \\
\hline Lower Middle Income & 1.16 & 0.56 & 4.62 & 1.45 & 21 \\
\hline Upper Middle Income & 0.35 & 0.27 & 2.80 & 1.27 & 13 \\
\hline High Income (non OECD) & -1.38 & 0.96 & 0.62 & 0.28 & 5 \\
\hline Africa & 0.83 & 1.13 & 6.14 & 5.22 & 25 \\
\hline Asia & 1.07 & 0.56 & 5.78 & 1.81 & 13 \\
\hline Latin-America & 0.32 & 0.30 & 3.24 & 1.55 & 22 \\
\hline except China and India & 0.65 & 0.95 & 4.89 & 3.54 & 58 \\
\hline China and India & 1.14 & 0.24 & 5.99 & 1.49 & 2 \\
\hline
\end{tabular}

Table 9: The benefits of international financial integration.

The table reports the population weighted average of the equivalent variation $\mu$. Year is 1995.

stands at 0.6. In other words, financial integration would only bring Togo much faster to a much impoverished steady state.

According to this interpretation, the difference between industrialized and emerging economies is not that the latter start with a large capital deficit that can be filled by capital inflows but rather that they are converging toward a much lower level of income. Although capital account opening can accelerate this convergence, the welfare benefit appears small when compared to the long-run inequality resulting from long run cross-country differences. This interpretation does not imply that countries are close to their steady state, simply that the steady states themselves are quite far from the steady state of a country like the United States.

Consider then, the gap between a country's income per capita in some reference year - say 1995 - and the steady-state income per capita in the U.S.: $y_{0} / y_{0}^{*, u s}$.We can think of economic development as a process that closes the 'development gap' between standards of living in emerging countries $\left(y_{0}\right)$ and their steady-state levels in the developed world $\left(y_{0}^{* u s}\right)$.

A key question for economic development consists in identifying the sources of this development gap. Do they reflect the fact that emerging countries are far away from their steady state? Do they reflect lack of domestic saving, possibly caused by a high capital wedge? Do they reflect high distortions or low returns in the accumulation of human capital? Or do they reflect low domestic productivity? To asnwer these questions, we decompose this 'development gap' into three components as follows:

$$
\frac{y_{0}}{y_{0}^{*, u s}}=\frac{\tilde{y}_{0}}{\tilde{y}^{*}} \cdot \frac{\tilde{y}^{*}}{\tilde{y}^{*, u s}} \cdot \frac{A_{0}^{\prime}}{A_{0}^{u s \prime}},
$$

where $\tilde{y}$ denotes output per efficient unit excluding the contribution of human capital $\left(y / A^{\prime}\right)$.

The first term reflects the gap coming from the fact that the country has not yet converged to its steady state. We refer to this term as the convergence gap. This gap is eliminated more quickly under financial integration. 
The second term reflects the cross-country differences in the efficiency of (physical and human) capital accumulation. We call it the distortion gap. It can be further decomposed into a physical capital and human capital components. Countries with a large distortion gap are poor because their domestic capital markets are distorted and/or because their human capital accumulation technology is very inefficient. ${ }^{31}$

The third term in equation (12) reflects differences in productivity between the domestic country and the United States that are not accounted for by human capital. We denote it the productivity gap. Countries with a large productivity gap are poor because they have a lower productivity than the United States after controlling for human capital.

Our decomposition is related to Hall and Jones (1999) and Jones (1997). Hall and Jones decompose relative output per worker into a relative capital, relative human capital and relative productivity term. Implicitly, their method includes a relative convergence gap term (the ratio of the convergence gap relative to the US convergence gap) that is allocated between the capital-output component and human capital components. Jones decomposes steady state relative output into its capital and productivity gap components. His focus on steady state output excludes a convergence term.

Table 10 reports summary development accounting statistics for each component in equation (12), in 1995. The first column reports the development gap. It is large, with non-OECD countries at only $11 \%$ of the U.S. steady state income per capita. The second, fifth and sixth columns report respectively the convergence, distortion and productivity gaps. Columns three and four further decompose the distortion gap into its physical and human capital components. It is immediate that while the convergence gap is substantial (0.74), it accounts for a small fraction of the development gap compared with the distortion (0.45) and productivity (0.3) gaps. These numbers imply that even with full convergence so that the convergence gap would be eliminated - the development gap would still equal only 0.14 $\left(0.45^{*} 0.3\right)$ of the U.S. steady state. Looking at the components of the distortion gap, it is also apparent that differences in schooling efficiency (0.54) account for a larger share than differences in investment rates (0.83).

To summarize, if capital mobility simply brings faster conditional convergence, it will not succeed in closing the gap between poor and rich countries. Differences in standards of living arise mostly from differences in productivity and human capital, especially for the poorest countries.

Figure 6 presents additional evidence on the role of the convergence gap. In each panel, the horizontal axis reports the log development gap $\ln \left(y_{0} / y_{0}^{*, u s}\right)$ against the $\log$ of each component in Table 10. As the figure makes clear, the convergence gap is the only component that is not positively correlated to the development gap. ${ }^{32}$ In other words, while poorer countries are, on average, less productive, accumulate less human and physical capital, there is no evidence that they are further away from their steady state.

\footnotetext{
${ }^{31}$ See Appendix A.

${ }^{32}$ An OLS regression yields a significant coefficient of -0.08 and an $\bar{R}^{2}$ of 0.21 .
} 


\begin{tabular}{|c|c|c|c|c|c|c|c|}
\hline & \multirow{2}{*}{$\begin{array}{c}\text { Development } \\
y_{0} / y_{0}^{*, u s}\end{array}$} & \multirow{2}{*}{$\begin{array}{c}\text { Convergence } \\
\tilde{y}_{0} / \tilde{y}^{*}\end{array}$} & \multicolumn{3}{|c|}{ Distortions } & \multicolumn{2}{|c|}{ Productivity } \\
\hline & & & $\begin{array}{c}\text { physical } \\
\text { capital }\end{array}$ & $\begin{array}{l}\text { human } \\
\text { capital }\end{array}$ & $\begin{array}{c}\text { total } \\
\tilde{y}^{*} / \tilde{y}^{*, u s}\end{array}$ & $A_{0} / A_{0}^{u s}$ & Obs. \\
\hline Non-OECD countries & 0.11 & 0.74 & 0.83 & 0.54 & 0.45 & 0.30 & 60 \\
\hline Low Income & 0.07 & 0.68 & 0.74 & 0.48 & 0.36 & 0.28 & 21 \\
\hline Lower Middle Income & 0.10 & 0.76 & 0.89 & 0.55 & 0.49 & 0.27 & 21 \\
\hline Upper Middle Income & 0.23 & 0.87 & 0.86 & 0.64 & 0.55 & 0.49 & 13 \\
\hline High Income & 0.44 & 0.74 & 1.20 & 0.82 & 0.98 & 0.61 & 5 \\
\hline Africa & 0.13 & 0.88 & 0.66 & 0.60 & 0.40 & 0.35 & 25 \\
\hline Asia & 0.09 & 0.70 & 0.86 & 0.52 & 0.45 & 0.27 & 13 \\
\hline Latin-America & 0.20 & 0.88 & 0.82 & 0.62 & 0.51 & 0.46 & 22 \\
\hline except China and India & 0.16 & 0.83 & 0.79 & 0.60 & 0.49 & 0.38 & 58 \\
\hline China and India & 0.07 & 0.68 & 0.86 & 0.50 & 0.43 & 0.26 & 2 \\
\hline
\end{tabular}

Table 10: Development Accounting. Population weighted averages. 1995.

\section{Implications for Future Research}

Based on a calibrated neoclassical growth model, we find that less developed countries do not benefit greatly from international financial integration. Less developed countries have far more to gain from improving their own domestic allocative efficiency than from an improvement in the allocative efficiency of the international financial system. This does not mean, however, that international financial integration is irrelevant for development. Indeed, it could be quite important, but if it is, this is through channels that are not captured by the basic neoclassical framework.

If most of the inequality in world income is explained by differences in productivity or domestic distortions, then the question of how the capital account regime interacts with domestic allocative efficiency seems quite relevant. Understanding the determinants of countries' productivity is a central question in development economics, which considers a very rich array of explanations: technological innovation and diffusion, the legal regime and property rights, policies and institutions, and their political economy underpinnings. The neoclassical approach makes the strong assumption that these determinants are not affected at all by the capital account regime. It would be interesting to explore the alternative: i.e. the channels by which international financial integration could raise or lower the productivity of less developed countries. ${ }^{33}$ In other terms, one might have to open the Pandora's box of development economics in order to really understand the benefits and costs of international financial integration.

There are various economic channels through which a less developed financially open country could "import" foreign productivity. First, international financial integration could increase the productivity of less developed economies by allowing inflows of Foreign Direct Investment (FDI) in industries where foreign firms enjoy a productivity advantage. ${ }^{34}$ The

\footnotetext{
${ }^{33}$ See Prasad, Rogoff, Wei and Kose (2003) for a general discussion of the effects of financial globalization on developing countries.

${ }^{34}$ See Borenzstein, de Gregorio and Lee (1998) and Carkovic and Levine (2002) for evidence (and opposite conclusions) on the impact of FDI on growth.
} 
entry of foreign capital could then increase the productivity of domestic labor both directly, and indirectly by encouraging productivity gains in the domestic firms that compete with the new entrants or by technological spillovers from foreign to domestic firms. One industry that deserves special emphasis and separate consideration in this regard, is the banking sector. In this case, the superior efficiency of foreign banks in allocating domestic saving could produce efficiency gains in the whole economy (Levine (1996)). This channel comes with important policy implications, since it would imply that the capital flows that need to be preserved are FDI, and not necessarily credit flows.

There are also more indirect channels through which international financial integration could affect the policies and governance of less developed countries. Opening the capital account could signal the quality of future policies (Bartolini and Drazen (1997)) or enhance the domestic government's commitment to good policies (Gourinchas and Jeanne (2003)). International financial integration induces countries to have good governance and a high level of transparency in order to attract foreign investors ex ante, and to maintain these good policies ex post in order to avoid a capital flight. In that respect, a central dimension of domestic policies is how respectful they are of private property rights - whose key role in development is widely acknowledged in economic and political science. There is a sense in which capital account openness deepens and extends the property rights of private agents, since it gives them the freedom to move their property abroad (Quinn (2000)). We present in Gourinchas and Jeanne (2003) a model where capital mobility ensures the respect of property rights, which is necessary for the development of an efficient, modern formal sector. On the other hand, the disruption induced by volatile capital flows could also have deleterious effects on domestic institutions, policies, and growth.

Finally, a lot of research remains to be done to assess the empirical relevance of these channels. While this can be done in many ways, the approach of this paper can be pursued at the empirical level by looking closely at the countries that experienced a productivity miracle in the postwar period. On the basis of our sample, we can identify eight countries that closed more 30 percent of their productivity gap with the U.S. between 1960 and $1995 .{ }^{35}$ All these countries had annual productivity growth in excess of three percent over this period. If the channels above mentioned are relevant, one would expect that financial integration played an important role in the productivity performance of at least some of these countries. This remains a question for further research.

${ }^{35}$ The list includes Korea, Botswana, Barbados, Israel, Cyprus, Mauritius, Hong Kong and Singapore. 


\section{References}

Athanasoulis, Stefano and Eric van Wincoop, "Growth Uncertainty and Risk-sharing," Journal of Monetary Economics, 2000, 45, 477-505.

Backus, David, Patrick Kehoe, and Fynn Kydland, "International Real Business Cycles," Journal of Political Economy, 1992, 100, 747-775.

Banerjee, Abhijit and Esther Duflo, "Do Firms Want to Borrow More? Testing Credit Constraints Using a Directed Lending Program," May 2002. mimeo M.I.T.

Barro, Robert and Jongwha Lee, "International Comparisons of Educational Attainment," Journal of Monetary Economics, 1993, 32, 363-394.

_ and _ _ , "International Data on Educational Attainment: Updates and Implications," Oxford Economic Papers, 2001.

_ and Xavier Sala-i-Martin, "Convergence," Journal of Political Economy, 1992, 100 (2), 223-51.

, Gregory Mankiw, and Xavier Sala-i-Martin, "Capital Mobility in Neoclassical Models of Growth," American Economic Review, 1995, 85 (1), 103-115.

Bartolini, Leonardo and Alan Drazen, "Capital Account Liberalization as a Signal," American Economic Review, 1997, 87, 138-154.

Bekaert, Geert, Campbell Harvey, and Christian Lundblad, "Does Financial Liberalization Spur Growth?," 2002. mimeo, Columbia University.

Bernanke, Ben and Refet Gürkaynak, "Is Growth Exogenous? Taking Mankiw, Romer and Weil seriously," in Ben Bernanke and Kenneth Rogoff, eds., N.B.E.R. Macroeconomics Annual, MIT Press Cambridge MA 2001, pp. 11-72.

Borenzstein, Eduardo, Jose de Gregorio, and Jongwha Lee, "How Does Foreign Investment Affect Growth?," Journal of International Economics, 1998, 45.

Calvo, Guillermo and Carmen Reinhart, "When Capital Flows Come to a Sudden Stop: Consequences and Policy," in Peter B. Kenen and Alexander K. Swoboda, eds., Reforming the International Monetary and Financial System, International Monetary Fund Washington D.C. 2000.

Carkovic, Maria and Ross Levine, "Does Foreign Direct Investment Accelerate Economic Growth?," 2002. mimeo, University of Minnesota.

Caselli, Francesco, Gerardo Esquivel, and Fernando Lefort, "Reopening the Convergence Debate: A New Look at Cross-Country Growth Empirics," Journal of Economic Growth, 1996, 1 (3), 363-89.

Cohen, Daniel and Marcelo Soto, "Why are Poor Countries Poor? A Message of Hope which involves the Resolution of a Becker-Lucas Paradox," September 2002. Center for Economic Policy Research Discussion Paper. 
de Melo, Jaime and David G. Tarr, A General Equilibrium Analysis of US Foreign Trade Policy, Cambridge, MA: MIT Press, 1992.

Duflo, Esther, "Schooling and Labor Market Consequences of School Construction in Indonesia: Evidence from an Unusual Policy Experiment," American Economic Review, 2001, 91 (4), 795-813.

Easterly, William and Ross Levine, "It's Not Factor Accumulation: Stylized Facts and Growth Models," The World Bank Economic Review, 2001, 15 (2), 177-219.

, Michael Kremer, Lance Pritchett, and Lawrence Summers, "Good Policy or Good Luck? Country Growth Performance and Temporary Shocks," Journal of Monetary Economics, 1993, 32, 459-483.

Eaton, Jonathan and Samuel Kortum, "International Technology: Theory and Measurement," International Economic Review, 1999, 40 (3).

Edison, Hali, Ross Levine, Luca Ricci, and Torsten Sloek, "International Financial Integration And Economic Growth," 2002. mimeo, International Monetary Fund.

Eichengreen, Barry and Michael Mussa, "Capital Account Liberalization: Theoretical and Practical Aspects," International Monetary Fund, Washington DC 1998. with G. Dell'Ariccia, E. Detragiache, G.M. Milesi-Ferretti and A. Tweedie. Occasional Paper No. 172.

Fischer, Stanley, "Capital Account Liberalization and the Role of the IMF," in "Should the IMF Pursue Capital-Account Convertibility?," Vol. 207, Essays in International Finance, Department of Economics, Princeton University, 1998, pp. 1-10.

Gollin, Douglas, "Getting Income Shares Right: Self Employment, Unincorporated Entreprise, and the Cobb-Douglas Hypothesis," June 1998. mimeo Williams College.

Gourinchas, Pierre-Olivier and Olivier Jeanne, "Capital Mobility, Property Rights and Economic Development," 2003. work in progress.

Hall, Robert and Charles Jones, "Why Do Some Countries Produce So Much More Output Per Worker than Others?," Quarterly Journal of Economics, 1999, 114 (1), $83-116$.

Henry, Peter B., "Capital Account Liberalization, The Cost of Capital, and Economic Growth," American Economic Review (Papers and Proceedings), May 2003, forthcoming.

Heston, Alan, Robert Summers, and Bettina Aten, "Penn World Table Version 6.1," October 2002. Center for International Comparisons at the University of Pennsylvania (CICUP).

Hsieh, Chang-Tai and Pete Klenow, "Relative Price and Relative Prosperity," 2003. mimeo, Dept. of Economics, Princeton University. 
Isham, Jonathan and Daniel Kaufman, "The Forgotten Rationale for Policy Reform: The Productivity of Investment Projects," Quarterly Journal of Economics, 1999, 114 (1), 149-84.

Jones, Charles, "Convergence Revisited," Journal of Economic Growth, 1997, 2, 131-53.

Levine, Ross, "Foreign Banks, Financial Development and Growth," in "International Financial Markets: Harminization cersus Competition" AEI Press Washington D.C. 1996, pp. 224-54.

Lucas, Robert E., Models of Business Cycles, New-York: Basil Blackwell, 1987.

Mankiw, N. Gregory, David Romer, and David Weil, "A Contribution to the Empirics of Economic growth," Quarterly Journal of Economics, 1992, 107 (2), 407-38.

Mendoza, Enrique and Linda Tesar, "The International Ramifications of Tax Reforms: Supply-Side Economics in a Global Economy," American Economic Review, 1998, 88 (1), 226-45.

Obstfeld, Maurice, "Risk-taking, Global Diversification and Growth," American Economic Review, 1994, 85, 1310-29.

and Kenneth Rogoff, "The Six Major Puzzles in International Macroeconomics: Is There a Common Cause?," in Ben Bernanke and Kenneth Rogoff, eds., N.B.E.R. Macroeconomics Annual, MIT Press Cambridge MA 2000, pp. 73-103.

Pallage, Stéphane and Michel Robe, "On the Welfare Cost of Economic Fluctuations in Developing Countries," International Economic Review, 2003, forthcoming.

Parente, Stephen and Edward Prescott, Barriers to Riches, Cambridge, MA: MIT Press, 2000.

Prasad, Eswar, Kenneth Rogoff, Shang-Jin Wei, and M. Ayhan Kose, "Effects of Financial Globalization on Developing Countries: Some Empirical Evidence," March 2003. mimeo, International Monetary Fund.

Psacharopoulos, George, "Returns to Investment in Education: A Global Update," World Development, 1994, 22, 1325-43.

Quinn, Dennis P., "Democracy and International Financial Liberalization," 2000. mimeo, McDonough School of Business, Georgetown University.

Rodrik, Dani, "Who Needs Capital Account Convertibility?," in "Should the IMF Pursue Capital-Account Convertibility?," Vol. 207, Essays in International Finance, Department of Economics, Princeton University, 1998, pp. 55-65.

Rutherford, Thomas F. and David G. Tarr, "Trade liberalization, product variety and growth in a small open economy: a quantitative assessment," Journal of International Economics, 2002, 56, 247-72. 


\section{Appendix A \\ The model with human capital}

This appendix presents the model with accumulation of human and physical capital.

\section{A.1 Assumptions}

1. The domestic economy produces a single homogenous good according to: $Y_{t}=K_{t}^{\alpha}\left(A_{t}^{\prime} H_{t}\right)^{1-\alpha}$ where $A_{t}^{\prime}$ grows at a constant rate $g^{*}$.

2. Human capital-augmented labor satisfies: $H_{t}=e^{\phi\left(E_{t}\right)} L_{t}$.

3. The representative firm in the economy acts competitively on factor markets. Assuming that physical capital depreciates at rate $\delta_{k} \geq 0$, factor prices satisfy:

$$
\begin{aligned}
& R_{t}=\alpha\left(\tilde{k}_{t} / h_{t}\right)^{\alpha-1}+1-\delta_{k} \\
& w_{t}=(1-\alpha)\left(\tilde{k}_{t} / h_{t}\right)^{\alpha},
\end{aligned}
$$

where $R_{t}$ denotes the domestic gross real interest rate, $w_{t}$ the normalized wage per efficiency unit of labor, and $\widetilde{k}=k / A^{\prime}$.

4. The representative domestic agent is infinitely lived and has time separable preferences defined over sequences of consumption per capita $\left\{c_{s}\right\}_{s=t}^{\infty}$ :

$$
U_{t}=\sum_{s=t}^{\infty} \beta^{s} N_{s} u\left(c_{s}\right),
$$

where $u(c) \equiv\left(c^{1-\gamma}-1\right) /(1-\gamma)$, and $u(c)=\ln (c)$ when $\gamma=1$.

5. Human capital accumulation depends upon the fraction of time devoted to education, $s_{t}$, according to

$$
E_{t+1}=\left(1-\delta_{e}\right) E_{t}+\theta s_{t},
$$

where $0<\underline{s} \leq s_{t} \leq \bar{s}<1$. We adopt $\bar{s}=0.5$ and $\underline{s}=0$.

6. Labor market clearing imposes $L_{t}=\left(1-s_{t}\right) N_{t}$.

7. There are two financial assets: the domestic capital stock $k_{t}$ and a riskless foreign bond $b_{t}$ that pays a constant gross world interest rate $R^{*}$, equal to the inverse of the growth-adjusted discount factor: $g^{* \gamma} / \beta$.

8. Investment in domestic capital is implicitly disorted at rate $\tau$, so that the private return to domestic capital is $(1-\tau) R_{t}$. The implicit rents generated by the distortion, $Z_{t} \equiv \tau R_{t} K_{t}$ are rebated in a lump-sum fashion to the representative agent.

9. The (normalized) flow budget constraint of the household is

$$
n g^{*}\left(\tilde{k}_{t+1}+\tilde{b}_{t+1}\right)=R^{*} \tilde{b}_{t}+(1-\tau) R_{t} \tilde{k}_{t}+w_{t} h_{t}+\tilde{z}_{t}-\tilde{c}_{t} .
$$




\section{A.2 Steady State}

Under these assumptions, physical and human capital converge to steady state values that are independent of the capital account regime, and satisfy ${ }^{36}$

$$
\begin{aligned}
s^{*} & =1-\frac{\frac{R^{*}}{n g^{*}}+\delta_{e}-1}{\theta \phi^{\prime}\left(E^{*}\right)} \\
E^{*} & =\frac{\theta}{\delta_{e}} s^{*} \\
h^{*} & =\left(1-s^{*}\right) e^{\phi\left(E^{*}\right)} \\
\tilde{k}^{*} & =\left(\frac{s_{k}(\tau)}{\delta_{k}+n \cdot g^{*}-1}\right)^{1 / 1-\alpha} h^{*},
\end{aligned}
$$

where:

$$
s_{k}(\tau)=\alpha \cdot \frac{\delta_{k}+n \cdot g^{*}-1}{\delta_{k}+R^{*} /(1-\tau)-1}
$$

is the domestic autarky investment rate that would prevail in steady state for an economy with capital wedge $\tau$.

\section{A.3 Financial autarky}

Under financial autarky, the economy must accumulate capital domestically $\left(\tilde{b}_{t}=0\right.$ for all $\left.t \geq 0\right)$. The Bellman equation associated with consumer program is:

$$
\begin{aligned}
v\left(\tilde{k}_{t}, E_{t}\right) & =\max _{\left\{\tilde{c}_{t}, s_{t}\right\}} u\left(\tilde{c}_{t}\right)+\frac{n g^{*}}{R^{*}} v\left(\tilde{k}_{t+1}, E_{t+1}\right) \\
\text { s.t. } n g^{*} \tilde{k}_{t+1} & =(1-\tau) R_{t} \tilde{k}_{t}+w_{t} h_{t}+\tilde{z}_{t}-\tilde{c}_{t} \\
E_{t+1} & =\left(1-\delta_{e}\right) E_{t}+\theta s_{t} \\
h_{t} & =\left(1-s_{t}\right) e^{\phi\left(E_{t}\right)} \\
\underline{s} & \leq s_{t} \leq \bar{s} ; k_{t} \geq 0 \\
k_{0}, E_{0} & \geq 0 \text { given, }
\end{aligned}
$$

where $v(\tilde{k}, E)=U(\tilde{k}, E) / A^{\prime 1-\gamma} N$ denotes the normalized welfare function. In the log case, we define $v(\tilde{k}, E)=\left(U(\tilde{k}, E)-\ln \left(A^{\prime}\right) /(1-n \beta)\right) / N$.

A competitive equilibrium consists of (1) a consumption function $c(\tilde{k}, E)$, an education policy $s(\tilde{k}, E)$ and a welfare function $v(\tilde{k}, E)$ that solves the consumer problem $(P)$ given the domestic real interest $R$ and wage $w ;(2)$ factor prices that satisfy equation (A.1); (3) markets that clear.

The first order conditions are:

$$
\begin{aligned}
\tilde{c}_{t}^{-\gamma} & =\frac{1}{R^{*}} v_{k}\left(\tilde{k}_{t+1}, E_{t+1}\right) \\
\frac{1}{R^{*}} v_{k}\left(\tilde{k}_{t+1}, E_{t+1}\right) w_{t} e^{\phi\left(E_{t}\right)} & =\frac{n g^{*}}{R^{*}} v_{E}\left(\tilde{k}_{t+1}, E_{t+1}\right) \theta-\bar{\mu}_{t}+\underline{\mu}_{t},
\end{aligned}
$$

where $\bar{\mu}_{t}$, resp. $\underline{\mu}_{t}$ are the Lagrange multiplier associated with the constraints with $\underline{s} \leq s_{t} \leq \bar{s}$.

\footnotetext{
${ }^{36}$ We assume that $1-\bar{s} \leq \frac{\frac{R^{*}}{n g^{*}}+\delta_{s}-1}{\theta \phi^{\prime}\left(E^{*}\right)} \leq 1-\underline{s}$. Equations (A.5) are obtained as the steady state solution to (A.7).
} 
The equilibrium conditions for consumption and education satisfy (for an interior solution, and after some manipulation)

$$
\begin{aligned}
\tilde{c}_{t}^{-\gamma} & =\frac{(1-\tau) R_{t+1}}{R^{*}} \tilde{c}_{t+1}^{-\gamma} \\
\tilde{c}_{t}^{-\gamma} w_{t} e^{\phi\left(E_{t}\right)} & =\frac{n g^{*}}{R^{*}} \tilde{c}_{t+1}^{-\gamma} w_{t+1} e^{\phi\left(E_{t+1}\right)}\left[\phi^{\prime}\left(E_{t+1}\right)\left(1-s_{t+1}\right) \theta+1-\delta_{e}\right] .
\end{aligned}
$$
tion.

The first equation is the standard Euler equation for the intertemporal allocation of consump-

The second equation characterizes the optimal intertemporal allocation of education. To understand the intuition behind this equilibrium condition, consider the following experiment. Suppose that at time $t$ the household decides to increase the fraction of time devoted to education by $\Delta s_{t}$. At time $t+1$, it adjusts education to revert to the optimal plan by time $t+2$. The increase in education today reduces efficient labor supply by $e^{\phi\left(E_{t}\right)} \Delta s_{t}$. This implies a decline in current income of $w_{t} e^{\phi\left(E_{t}\right)} \Delta s_{t}$ and a marginal utility loss of $\tilde{c}_{t}^{-\gamma} w_{t} e^{\phi\left(E_{t}\right)} \Delta s_{t}$. This is the left hand side of the equilibrium condition. At time $t+1$, educational attainment equals $E_{t+1}+\theta \Delta s_{t}$. This increases efficient labor supply by $e^{\phi\left(E_{t+1}\right)}\left(1-s_{t+1}\right) \phi^{\prime}\left(E_{t+1}\right) \theta \Delta s_{t}$. To revert to the optimal plan by $t+2$, education needs to be adjusted by $-\Delta s_{t}\left(1-\delta_{e}\right)$. This increases current hours by $e^{\phi\left(E_{t+1}\right)}\left(1-\delta_{e}\right) \Delta s_{t}$. Adding these two terms, multiplying by the wage $w_{t+1}$ and the marginal utility of wealth $\tilde{c}_{t+1}^{-\gamma}$ and discounting back to today at rate $n g^{*} / R^{*}$, gives the marginal utility gain on the right hand side of the equilibrium condition.

One can verify that the log-linearized dynamic system admits two eigenvalues outside the unit circle and is saddle-point stable. Starting from $\tilde{k}_{0}$ and $E_{0}$ the economy evolves along the stable arm of the dynamic system in $(\tilde{c}, s, \tilde{k}, E)$ and converges towards $\left(\tilde{c}^{*}, s^{*}, \tilde{k}^{*}, E^{*}\right)$.

We solve numerically this dynamic system for equilibrium consumption rules $\tilde{c}(\tilde{k}, E)$ and education rule $s(\tilde{k}, E)$ as well as the derivative of the value function $v_{E}(\tilde{k}, E)$, on a grid $\left(\tilde{k}_{i}, E_{j}\right)_{i, j}$ around the steady state $\left(\tilde{k}^{*}, E^{*}\right)$. Figure 7 presents the optimal consumption and education rules for various educational attainments.

Denote $U_{\text {aut }}\left(\tilde{k}_{0}, E_{0}\right)$ the welfare of the representative agent with initial capital $\tilde{k}_{0}$ and human capital $E_{0}$. By assumption, $U_{\text {aut }}\left(\tilde{k}_{0}, E_{0}\right)=v^{a}\left(\tilde{k}_{0}, E_{0}\right) A_{0}^{\prime 1-\gamma} N_{0} \cdot{ }^{37}$

\section{A.4 Financial integration}

Assume now that the economy integrates financially with the rest of the world at time 0 . Assume the economy is sufficiently small so as not to influence the world interest rate $R^{*}$.

Equating domestic and foreign returns to capital pins down the ratio of physical to human capital-augmented labor input:

$$
\begin{aligned}
\tilde{k}_{t} & =\left(\frac{s_{k}(\tau)}{\delta_{k}+n g^{*}-1}\right)^{1 / 1-\alpha} h_{t} \\
& \equiv \omega(\tau) h_{t},
\end{aligned}
$$

and the -constant- domestic wage $w=(1-\alpha) \omega(\tau)^{\alpha}$.

Equation (A.8) implies that capital flows are determined by the ratio of physical to human capital, not by the amount of capital relative to steady state.

\footnotetext{
${ }^{37}$ For the $\log$ case, $U_{\text {aut }}\left(\tilde{k}_{0}, E_{0}\right)=\left(v^{a}\left(\tilde{k}_{0}, E_{0}\right)+\ln \left(A_{0}^{\prime}\right) /(1-\beta n)\right) N_{0}$.
} 
Since the world interest rate equals the growth-adjusted discount rate, consumption also jumps to a constant level, consistent with the intertemporal budget constraint:

$$
\tilde{c}=\left(R^{*}-n g^{*}\right)\left(k_{0}+\frac{\chi(\tau)}{R^{*}} \sum_{t=0}^{\infty}\left(\frac{n g^{*}}{R^{*}}\right)^{t} h_{t}\right),
$$

where $\chi(\tau)=(1-\alpha(1-\tau)) \omega(\tau)^{\alpha}+\tau\left(1-\delta_{k}\right) \omega(\tau) . \chi(\tau) h_{t}$ represents labor income net of transfers.

This consumption level differs from the steady state autarky consumption $\tilde{c}^{*}$. Subtracting $\tilde{c}$ from $\tilde{c}^{*}$, we obtain:

$$
\tilde{c}^{*}-\tilde{c}=\left(R^{*}-g^{*} n\right)\left(\tilde{k}^{*}-\tilde{k}_{0}\right)+\left(1-\frac{n g^{*}}{R^{*}}\right) \chi(\tau) \sum_{t=0}^{\infty}\left(\frac{n g^{*}}{R^{*}}\right)^{t}\left(h^{*}-h_{t}\right) .
$$

This expression has two terms. The first one obtains in a model with physical capital only. It represents the - growth-adjusted- annuity value of foreign debt if the country were to borrow immediately the amount $k^{*}-k_{0}$ to attain its steady state. Consumption is lower since the country needs to roll-over foreign debt permanently. The second term reflects the effect of the accumulation path for human capital on domestic labor income $\chi(\tau) h_{t}$. If human capital is increasing, the country will borrow against higher future labor income. This second effect tends also to depress long run consumption.

Convergence in $h$ is not instantaneous, since human capital can only be accumulated domestically. Even if the economy starts with the correct amount of physical capital $\tilde{k}_{0}=\tilde{k}^{*}$, consumption can be lower than in the autarky steady state if initial human capital is also below steady state, $h_{0}<h^{*}$.

Denote welfare under integration as $U_{\text {int }}\left(\tilde{k}_{0}, E_{0}\right)$. It is immediate that it satisfies

$$
\begin{aligned}
U_{\text {int }}\left(\tilde{k}_{0}, E_{0}\right) & =v^{i}\left(\tilde{k}_{0}, E_{0}\right) A_{0}^{1-\gamma} \\
& =\frac{u(\tilde{c})}{1-n g^{*} / R^{*}} A_{0}^{\prime 1-\gamma}
\end{aligned}
$$

and depends only upon the sequence of human capital-augmented labor inputs $\left\{h_{t}\right\}$. Hence, maximizing $U_{\text {int }}\left(\tilde{k}_{0}, E_{0}\right)$ is equivalent to solving the following problem

$$
\begin{aligned}
W\left(E_{t}\right)= & \max _{\left\{s_{t}\right\}} \sum_{t=0}^{\infty}\left(\frac{n g^{*}}{R^{*}}\right)\left(1-s_{t}\right) e^{\phi\left(E_{t}\right)} \\
& \text { s.t. } E_{t+1}=\left(1-\delta_{e}\right) E_{t}+\theta s_{t} \\
& \underline{s} \leq s_{t} \leq \bar{s}
\end{aligned}
$$

$E_{0}$ given

The first order and envelope conditions associated with this problem are

$$
\begin{aligned}
e^{\phi\left(E_{t}\right)} & =\left(\frac{n g^{*}}{R^{*}}\right) W^{\prime}\left(E_{t+1}\right) \theta+\underline{\mu}_{t}-\bar{\mu}_{t} \\
W^{\prime}\left(E_{t}\right) & =\left(1-s_{t}\right) \phi^{\prime}\left(E_{t}\right) e^{\phi\left(E_{t}\right)}+\left(\frac{n g^{*}}{R^{*}}\right) W^{\prime}\left(E_{t+1}\right)\left(1-\delta_{e}\right)
\end{aligned}
$$

where $\bar{\mu}_{t}$, resp. $\underline{\mu}_{t}$ are the Lagrange multiplier associated with the constraints with $\underline{s} \leq s_{t} \leq \bar{s}$. 
One can show that the optimal schooling policy is bang-bang and oscillates around the steady state. The linearized system exhibits a negative root, so that the state variable $E_{t}$ 'bounces' around its steady state value $E^{*}$. This feature of the discrete time problem would go away in the continuous time limit (in continuous time, a predetermined variable cannot 'jump' over the steady state). We directly use the solution to the continuous limit of the model that converges to the steady state in finite time.

The optimal education policy that solves problem $(Q)$ then takes a simple form:

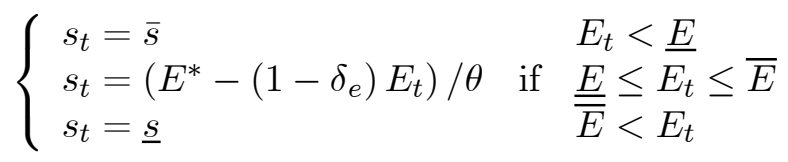

where $\bar{E}=\left[E^{*}-\theta \underline{s}\right] /\left(1-\delta_{e}\right)$ and $\underline{E}=\left[E^{*}-\theta \bar{s}\right] /\left(1-\delta_{e}\right) \cdot{ }^{38}$

\section{A.5 Welfare Gains}

To compare welfare under the two scenarios, we define the Hicksian equivalent variation $\mu\left(\tilde{k}_{0}, E_{0}\right)$ as the percentage increase in consumption that brings the welfare of the representative agent under autarky up to its level under integration. That is, $\mu\left(\tilde{k}_{0}, E_{0}\right)$ satisfies

$$
\frac{u(\tilde{c})}{1-n g^{*} / R^{*}} A_{0}^{1-\gamma}=A_{0}^{\prime 1-\gamma} \sum_{t=0}^{\infty}\left(\frac{n g^{*}}{R^{*}}\right)^{t} u\left(\tilde{c}_{t}\left(1+\mu\left(\tilde{k}_{0}, E_{0}\right)\right)\right),
$$

where $\widetilde{c}$ denotes the -constant- consumption level under integration and $\left\{\tilde{c}_{t}\right\}_{0}^{\infty}$ denotes the consumption profile under autarky. Replacing $U^{a}\left(\tilde{k}_{0}, E_{0}\right)$ and solving out for or $\mu\left(\tilde{k}_{0}, E_{0}\right)$,

$$
\mu\left(\tilde{k}_{0}, E_{0}\right)=\left(\frac{U_{\text {int }}\left(\tilde{k}_{0}, E_{0}\right)}{U_{\text {aut }}\left(\tilde{k}_{0}, E_{0}\right)}\right)^{\frac{1}{1-\gamma}}-1
$$

for $\gamma \neq 1$. In the log case, we obtain

$$
\mu\left(\tilde{k}_{0}, E_{0}\right)=e^{(1-\beta n)\left(U_{\text {int }}\left(\tilde{k}_{0}, E_{0}\right)-U_{\text {aut }}\left(\tilde{k}_{0}, E_{0}\right)\right) / N_{0}}-1 .
$$

Similarly, we can define $\mu^{c}\left(\tilde{k}_{0}, E_{0}\right)$ as the Hicksian compensating variation, that is, the percentage decrease in consumption that makes the agent in the integrated economy indifferent between the two convergence paths: $\mu^{c}\left(\tilde{k}_{0}, E_{0}\right)=\frac{\mu\left(\tilde{k}_{0}, E_{0}\right)}{\mu\left(\tilde{k}_{0}, E_{0}\right)+1}$. In general, the compensating variation is smaller than the equivalent variation.

\section{A.6 Marginal Welfare Gains}

Assume that at time 0 the capital inflow authorized at $t+1$ is increased by $d \kappa_{t+1}=c_{t+1} d c / c$. With log-preferences the discounted welfare gain at time 0 is equal to

$$
d U_{0}=\left(\sum_{t=0}^{+\infty} \beta^{t+1}\left(R_{t+1}-R^{*}\right)\right) \frac{d c}{c},
$$

\footnotetext{
${ }^{38}$ That $\underline{E} \leq E^{*} \leq \bar{E}$ derives from $\underline{s} \leq s^{*} \leq \bar{s}$.
} 
and the resulting equivalent variation satisfies:

$$
\sum_{t=0}^{\infty} \beta^{t} \ln (1+\mu)=d U_{0}
$$

so that, for small variations:

$$
\mu \approx(1-\beta) \sum_{t=0}^{+\infty} \beta^{t+1}\left(R_{t+1}-R^{*}\right) \frac{d c}{c} .
$$

Using the definition of the permanent value of the interest rate $\hat{R}$, equation (10) obtains.

\section{A.7 Development Accounting}

The convergence gap is equal to

$$
\frac{\tilde{y}_{0}}{\tilde{y}^{*}}=\left(\frac{\delta+n+g^{*}}{s_{k}(\tau)} \cdot \frac{k_{0}}{y_{0}}\right)^{\frac{\alpha}{1-\alpha}} \frac{h_{0}}{h^{*}} .
$$

The steady state gap is equal to

$$
\frac{\tilde{y}^{*}}{\tilde{y}^{*, u s}}=\left(\frac{s_{k}(\tau)}{\delta_{k}+g^{*} \cdot n-1} / \frac{s_{k}\left(\tau^{u s}\right)}{\delta_{k}+g^{*} \cdot n^{u s}-1}\right)^{\frac{\alpha}{1-\alpha}} \frac{h^{*}}{h^{*, u s}} .
$$

The first term on the right hand side reflects the steady state differences in capital-output ratio: $\left(k^{*} / y^{*}\right) /\left(k^{* u s} / y^{* u s}\right)$. The second term reflects differences in steady state human capital accumulation $h^{*} / h^{*, u s}$.

\section{Appendix B Calibrating the model}

\section{B.1 Constructing human capital stocks}

We adopt a piecewise linear representation of the returns to schooling consistent with the empirical evidence in Psacharopoulos (1994). The marginal return to education is set to $13.4 \%$ for the first four years of education, to $10.1 \%$ for the next four, and to $6.8 \%$ subsequently.

The concept of human capital we use is the average educational attainment for people over age 25 , i.e. the average number of years of schooling in the population older than 25 . This is a stock measure, as needed for the theory. To measure $E_{t}$, we rely on the Barro and Lee (2001) updated dataset (see also Jones (1997)). This dataset constructs educational attainment every five years from 1960 to 2000 for a sample of 138 countries, according to the following perpetual inventory method:

$$
E_{t}=\left(1-\delta_{25, t}\right) E_{t-5}+\delta_{25, t} \sum_{j} \pi_{j} u_{j}
$$

where $E_{t}$ represents educational attainment in year $t, \pi_{j}$ represents the educational attainment rate for cell $j$-i.e. the fraction of a school-age cohort enrolled in education cell $j$ - and $u_{j}$ represents the duration of cell $j$, i.e. the number of years of education for that cell. $\delta_{25, t}$ represents the depreciation rate for educational attainment and is equal to the fraction of the population aged 
25-29 (see Barro and Lee (1993) for a derivation). Barro and Lee provide data on six educational categories: incomplete primary, primary, incomplete secondary, secondary incomplete higher and higher education.

Using equation B.1, steady state educational attainment $E^{*}$ is defined as:

$$
E^{*}=\sum_{j} \pi_{j}^{*} u_{j}
$$

We measure steady state enrollment rates $\pi_{j}^{*}$ and durations $u_{j}^{*}$ using the latest available data. Because this data is not directly available from the Barro and Lee dataset, we use data from the UNESCO World Education Report, 2000 that reports data on duration for primary, incomplete secondary and secondary education as well as net enrollment rates for primary and secondary education and gross enrollment rates for tertiary education for the year 1996 (or the latest available year when 1996 is not available). We assume, as Barro and Lee, that incomplete cycles have a duration equal to half the full cycle and that higher education lasts four years. Gross enrollment ratios refer to the total enrollment in a given education group, regardless of age, divided by the population of the age group which officially corresponds to that education cell. The net enrollment ratio only includes enrollment for the age group corresponding to the official school age of primary education. Defining PRI, SEC and HIGH as the UNESCO enrollment rates, we obtain:

$$
\begin{aligned}
\pi_{p}^{*} & =P R I-S E C \\
\pi_{s}^{*} & =S E C-H I G H \\
\pi_{h}^{*} & =H I G H .
\end{aligned}
$$

We split the UNESCO enrollment rates into complete and incomplete cycles using the Barro and Lee rates of completion for primary, secondary and higher education.

Lastly, we annualize the depreciation rate and enrollment rates as follow: Define $s_{t}$ the annual investment in schooling that satisfies:

$$
E_{t+1}=\left(1-\delta_{e}\right) E_{t}+\theta s_{t}
$$

as in the model. Assuming that $s_{t}$ is constant between $t-5$ and $t$, it follows that

$$
E_{t+5}=\left(1-\delta_{e}\right)^{5} E_{t-5}+\frac{\theta}{\delta_{e}} s_{t}\left[1-\left(1-\delta_{e}\right)^{5}\right] .
$$

Identifying with (B.1), we obtain:

$$
\begin{aligned}
\delta_{e} & =1-\left(1-\delta_{25, t}\right)^{1 / 5} \\
s_{t} & =\frac{\delta_{e}}{\theta} \sum_{j} \tilde{\pi}_{j t-n_{j}} \tilde{u}_{j} \\
& =\frac{1}{\theta} \frac{\delta_{e}}{\delta_{25, t}}\left[E_{t}-\left(1-\delta_{25, t}\right) E_{t-5}\right] \\
s^{*} & =\frac{\delta_{e}}{\theta} \sum_{j} \pi_{j} u_{j}=\frac{\delta_{e} E^{*}}{\theta}
\end{aligned}
$$

Given an estimate of $E^{*}$ and $\delta_{e}$, an estimate for $\theta$ is obtained from equation (A.5) as

$$
\theta=\frac{\frac{R^{*}}{n g}-1+\delta_{e}\left[1+E^{*} \phi^{\prime}\left(E^{*}\right)\right]}{\phi^{\prime}\left(E^{*}\right)} .
$$




\section{B.2 Constructing steady state capital stocks}

Using data from Heston et al. (2002) Mark 6.1, we measure the average investment share $\hat{s}_{k}$ in gross GDP from 1985 to 1995 . We then assume that the observed average investment rate is a good approximation to the investment rate that would obtain in steady state under autarky:

$$
\hat{s}_{k}=\alpha \cdot \frac{\delta_{k}+n \cdot g^{*}-1}{\delta_{k}+R^{*} /(1-\tau)-1} .
$$

This approach is similar to Mankiw et al. (1992) who assume constant saving rates in their tests of unconditional and conditional convergence. Similarly, the literature on calibrated business cycle models often interprets historical averages as equivalent to steady state values (see Mendoza and Tesar (1998) for an application to tax reform). ${ }^{39}$

The capital ratio then follows:

$$
\ln \left(\frac{k_{0}}{k^{*}}\right)=\frac{1}{1-\alpha}\left[\ln \left(\frac{k_{0}}{y_{0}}\right)-\ln \left(\frac{k^{*}}{y^{*}}\right)\right]+\ln \frac{h_{0}}{h^{*}} .
$$

\footnotetext{
${ }^{39}$ It is important to emphasize that this assumption does not imply that countries are estimated to be close to their steady state. As a famous counter example, consider the Solow model. It assumes a constant saving rate, but imposes no restrictions on the proximity of countries to their steady state.
} 


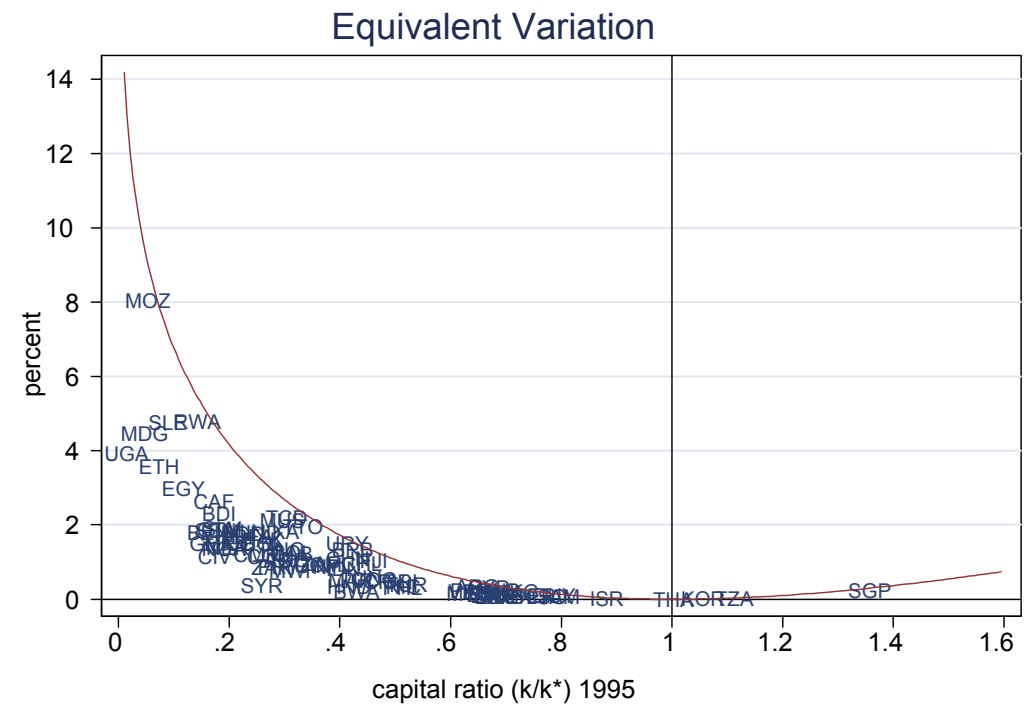

Figure 1: International Financial Integration, benchmark case.

The thin solid line corresponds to the theoretical gains from international financial integration as a function of the capital ratio $k / k^{*}$ for a country with the same population growth rate as the U.S.

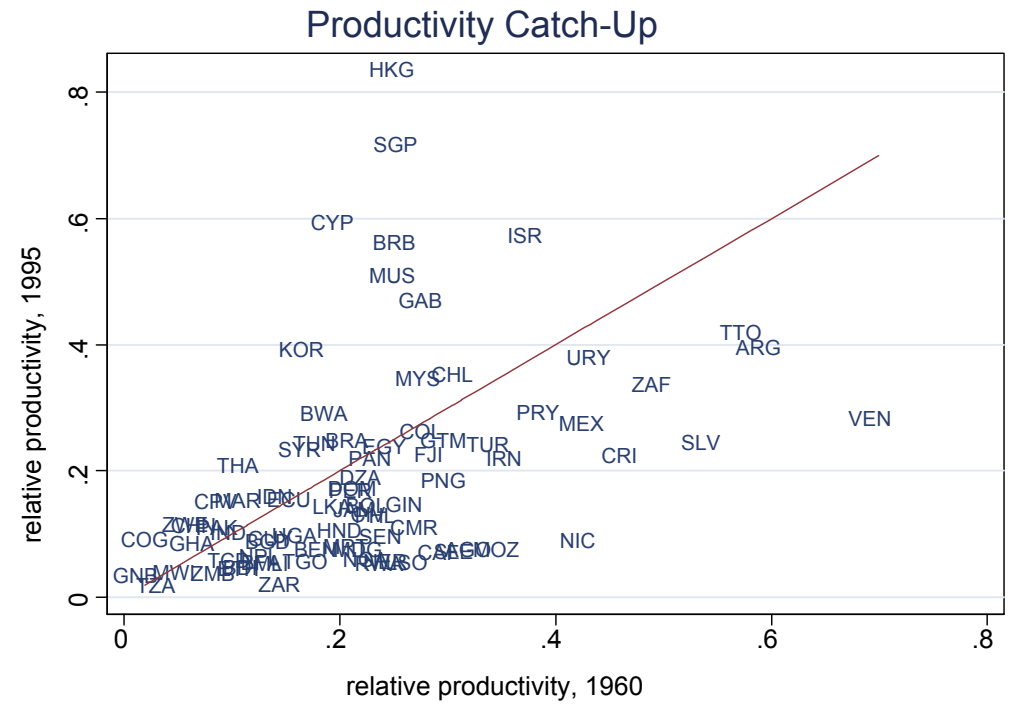

Figure 2: Relative Productivity Change, $A_{0} / A_{0}^{u s}$ for non-OECD economies, 1960 to 1995. 

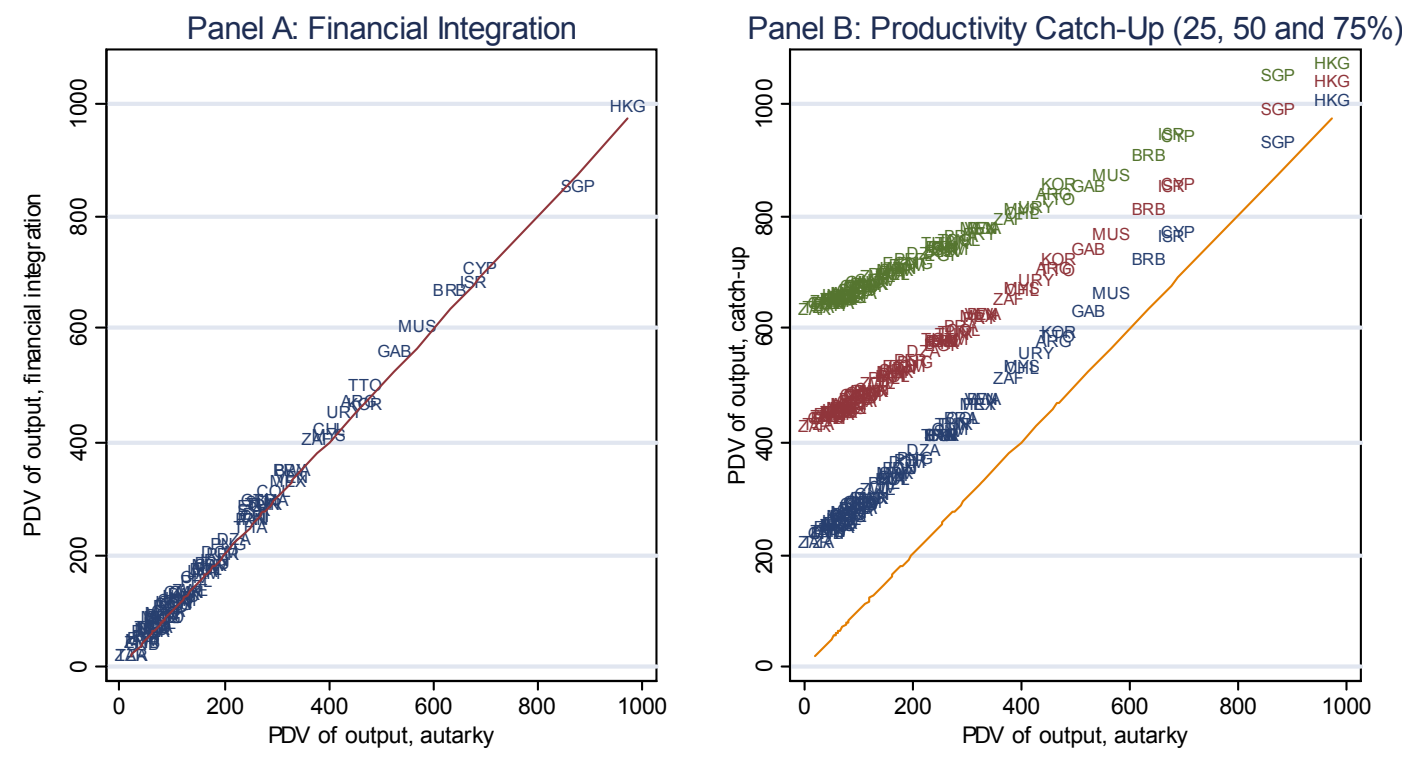

Figure 3: Domestic Output, financial integration and productivity catch-up.Change in the PDV of domestic output from financial integration and a $25 \%$ productivity catch-up with the United States under autarky. Year is 1995 . 

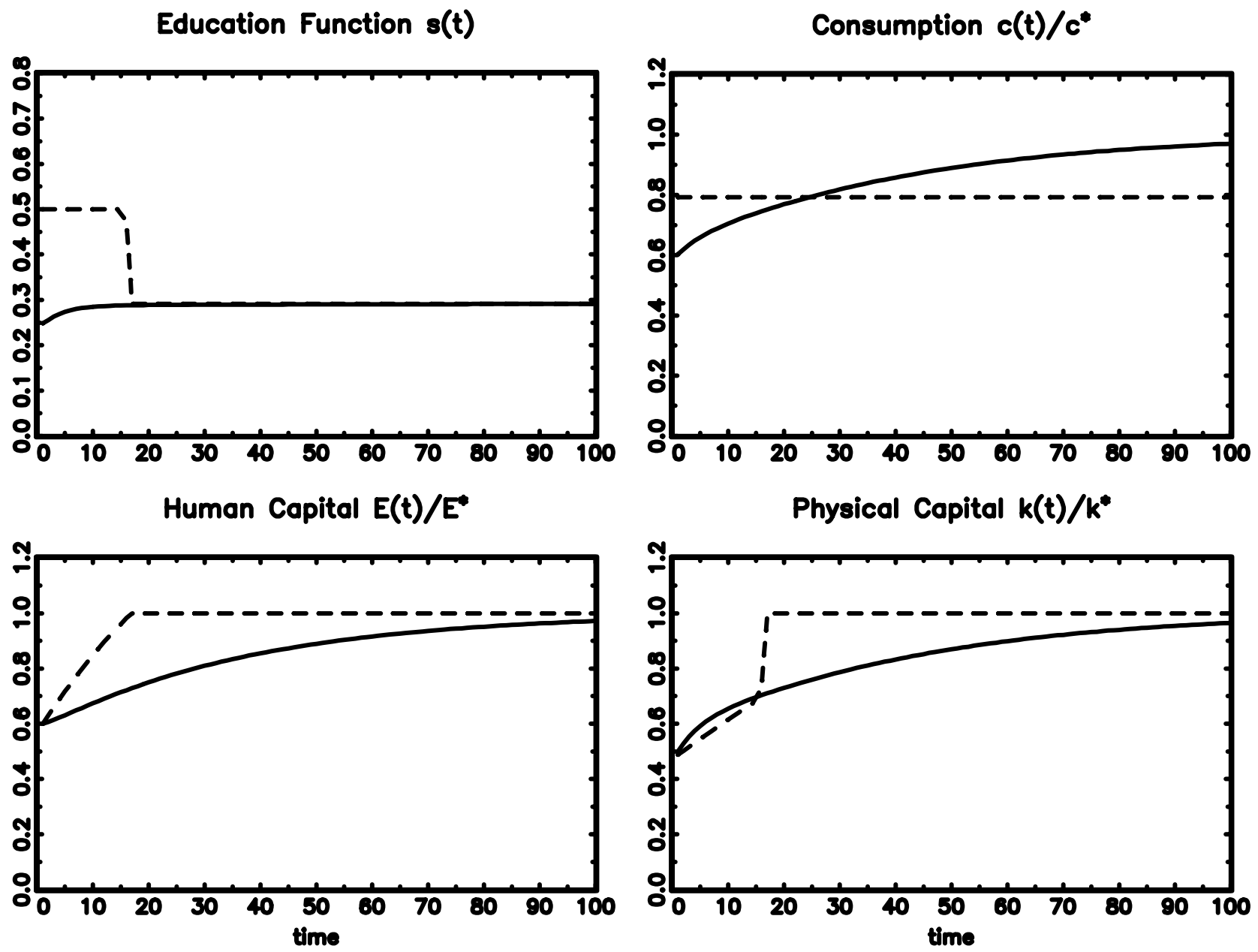

Figure 4: Sample Convergence Trajectories; Thick line: Autarky. Dashed line: Financial Integration. $k_{0}=0.5 k^{*}$ and $E_{0}=0.6 E^{*}$. Calibrated to the US economy. See footnote 23 for parameter values. 


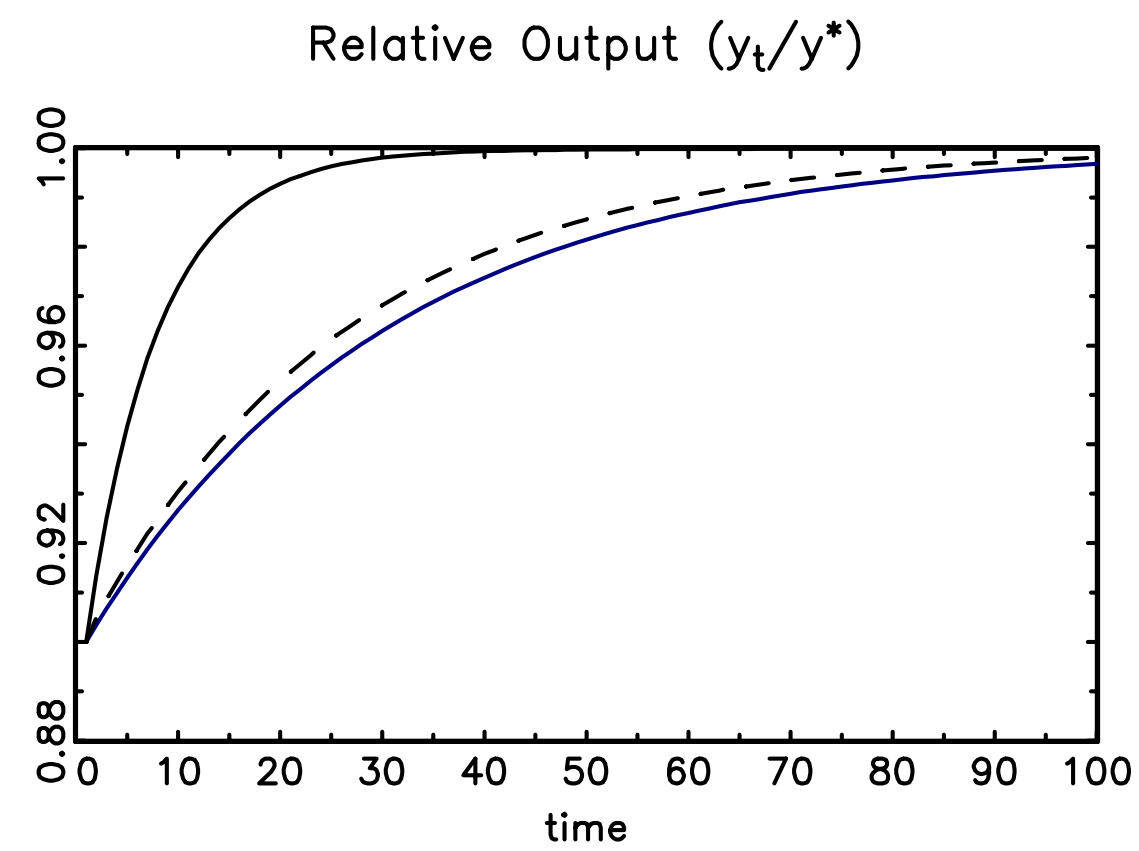

Figure 5: Relative Output Path; Solid black line: physical capital only; Dashed black line: model with distortions; Solid blue line: model without distortions. Parameters are calibrated to the average developing country. 
Panel A: Convergence Gap

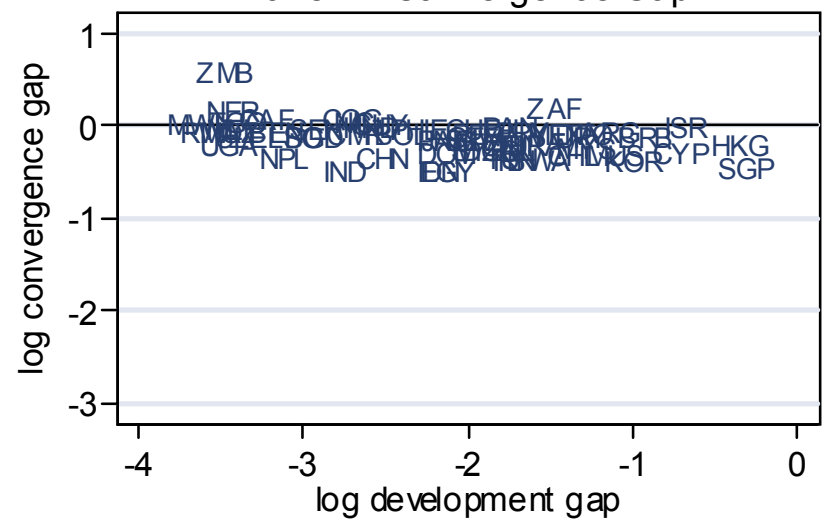

Panel C: Human Capital Gap

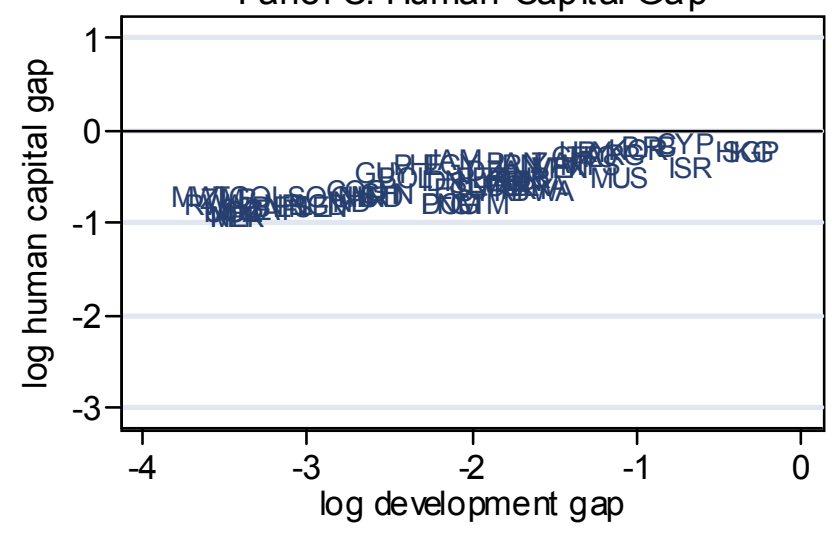

Panel B: Physical Capital Gap

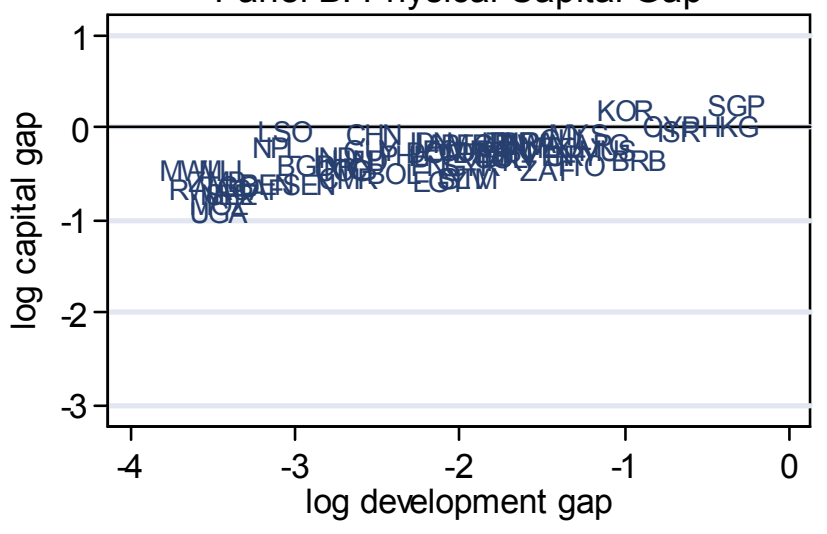

Panel D: Productivity Gap

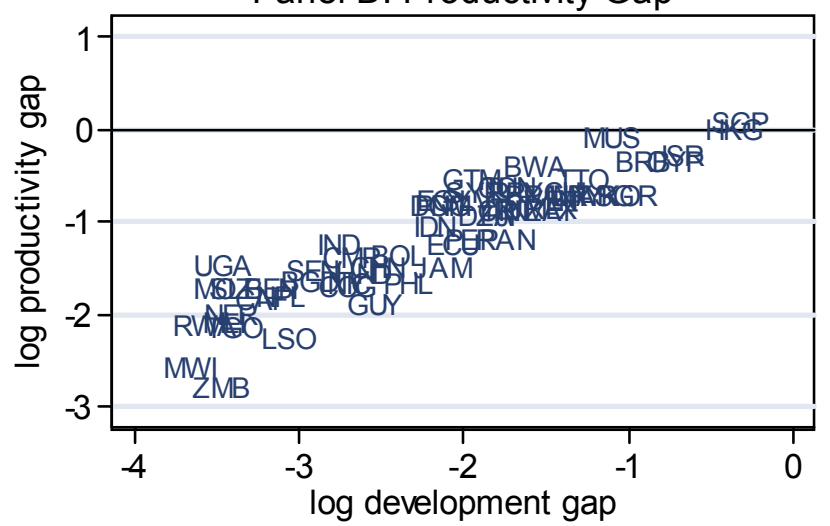

Figure 6: Development Accounting. Year is 1995. 


\section{Consumption Function $c(k, E)$}

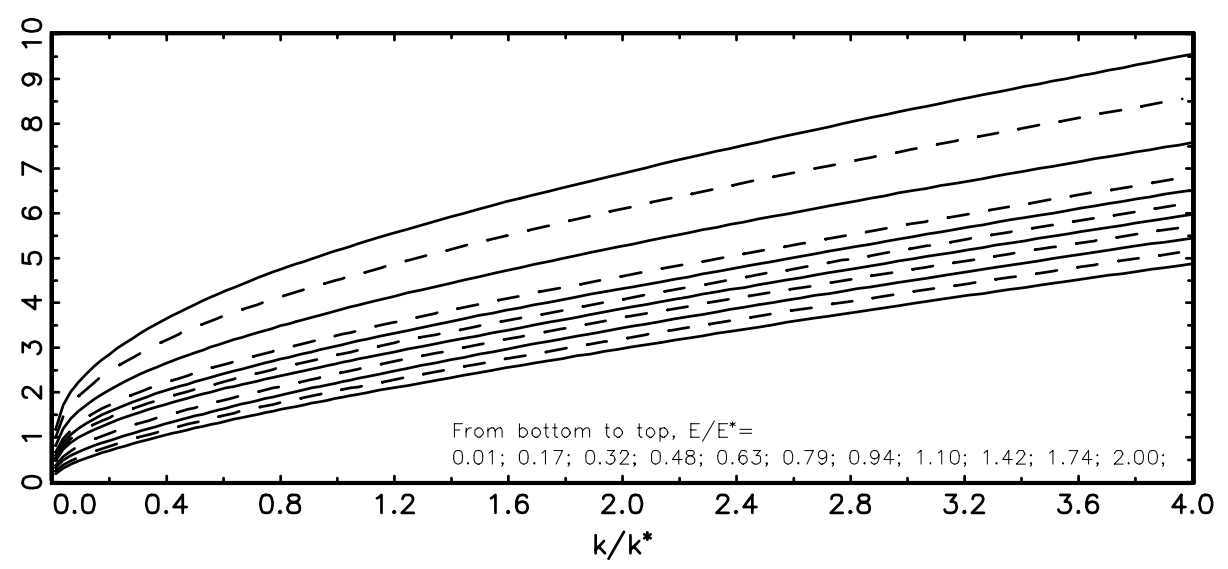

\section{Education Function $s(k, E)$}

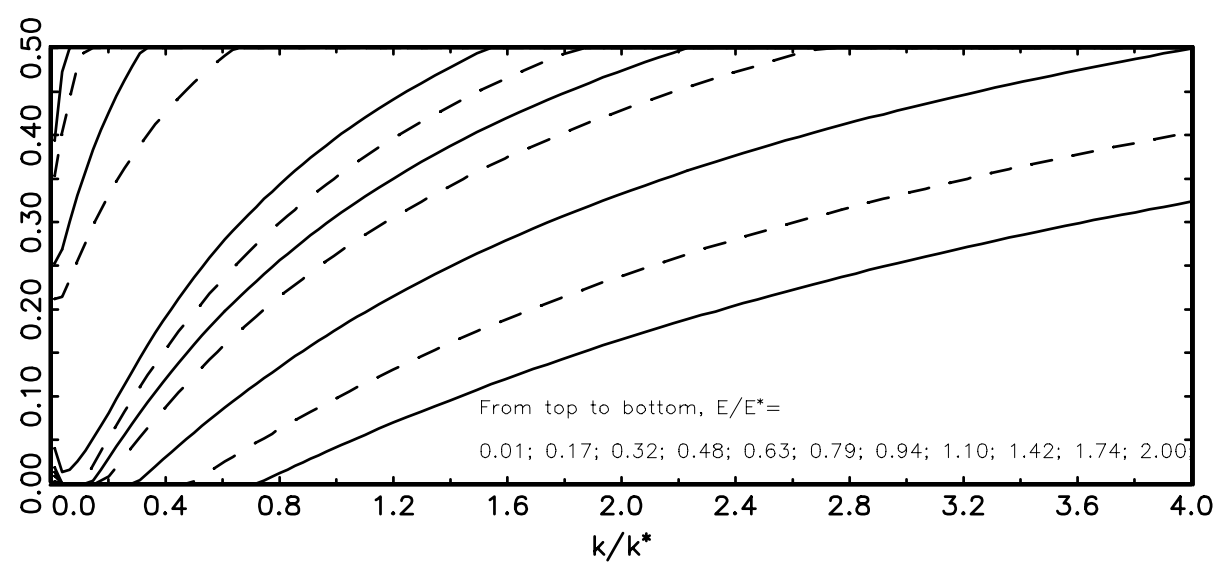

Figure 7: Optimal Consumption and Education rules for various Educational Attainment. Calibrated to the US economy. See footnote 23 for parameter values. 